\title{
Toward the Classical Saga
}

\section{The Preclassical Texts}

"The origins of the classical prose," wrote E. O. G. TurvillePetre, "can perhaps be discerned best if Icelandic literature of pre-classical ages is considered."' This proposition is hardly a fresh one-scholars have long wondered about the extent to which thirteenth-century literary developments may have been prefigured in the twelfth century-but the fact that it could be the point of departure for a major work as recently as 1953 suggests just how inconclusive earlier treatments have been. The task of establishing continuities is not as straightforward as it may seem. One problem is the paucity of extant texts from the early period. A second problem is that those texts that do survive are not entirely apposite, consisting of translations of foreign works, history writing (partly in Latin) of a fairly standard sort, and royal biographies of a strongly clerical stamp. A third problem has to do with the fact that these texts appear in rapid succession, and although we have some idea of their relative chronology, we get little sense of literary phases displacing one another and evolving toward the vernacular and secular masterpieces of the thirteenth century. Still, if these early documents do not offer a neat prehistory of the saga phenomenon as a whole, they provide an insight into certain of its aspects, not the least of which is the category of composition, mentioned only in passing in Turville-Petre's study.

'E. O. G. Turville-Petre, Origins of Icelandic Literature (Oxford: Clarendon, 1953), p. v. 
With the classical patterns of composition in mind, therefore, we may review some early texts in the historical tradition which may have a bearing on the rise of the saga.

Sæmundr and Ari. The first history of the Norwegian kings of which we have record is that of the Icelander Sæmundr the Wise (died 1133). Nothing survives of Sæmundr's work save the two sentences cited in Oddr's saga of Olaffr Tryggvason. ${ }^{2}$ Sæmundr's work was an important source for Ari and other early writers, however, and their references to it indicate something of its scope and content (it appears to have ranged rather widely, even into Icelandic matter), but next to nothing is known of its style and composition. Snorri (in his prologues to Heimskringla and the Separate Saga of Saint Óláfr) names Ari as the first person to write learned works in the vernacular, from which it may be inferred that Sæmundr's history was in Latin. Tradition holds that Sæmundr studied in France.

The only surviving work by Ari (died 1148) is the ten-page Íslendingabók (Libellus Islandorum), written in the early twelfth century. ${ }^{3}$ Purporting to be a summary history of Iceland from the time of its settlement down through the life of Bishop Gizurr, the Íslendingabók may seem to the modern eye somewhat arbitrary in its selection and coverage of events. ${ }^{4}$ Although Ari makes a point of synchronizing events in Iceland with those in Europe, ${ }^{5}$ there is no hint, in this very spare and synoptic treatment of local matters, of double lines of action. Certain stylistic traits are reminiscent of later saga prose, but there is no discernible point of

2On Sæmundr's authorship, see Svend Ellehøj, Studier over den aldste norrone historieskrivning, Bibliotheca Arnamagnæana, 26 (Copenhagen: Munksgaard, 1965), pp. 15-25.

${ }^{3}$ On Ari's authorship, ibid., pp. $26-84$.

"Andreas Heusler, "Are's Islendingabokk und Libellus Islandorum," Arkiv för nordisk filologi, 23 (1907), 319-37.

sFor example, "Á pví ári enu sama obiit Paschalis secundus páfi fyrr en Gizurr byskup ok Baldvini Jórsalakonungr ok Arnaldus patriarcha í Híerúsalem ok Philippus Svíakonungr, en síðarr et sama sumar Alexíus Grikkjakonungr; pá hafơi hann átta vetr ens fjorơa tegar setit at stóli í Miklagarơi (In that same year Pope Paschal the Second died, before Bishop Gizurr; Baldwin, King of Jerusalem; Arnulf, Patriarch of Jerusalem; Philip, King of the Swedes; and, later the same summer, Alexius, Emperor of the Greeks-at that time he had occupied the throne at Constantinople for 38 years"-chap. 10). 
contact on the level of composition. There are no transitional formulas.

Landnámabók. There are five extant versions of Landnámabók, three medieval and two seventeenth-century, all thought to derive from a now-lost version by Styrmir Kárason (died 1245). ${ }^{6}$ Styrmir was probably operating within an established tradition; it is thought that some kind of settlement book existed at least a century earlier-perhaps, as some references suggest, authored by Ari. The second chapter of Ari's Íslendingabók consists of an abbreviated list of settlers and their progeny, and it is possible that an older version, the Liber Islandorum, also contained similar settlement records. In the form we now have it, Landnámabók names about 400 original settlers of Iceland and specifies what land they took. The organization is geographic, moving clockwise around the island. The genealogies are typically made to extend backward into previous generations in Norway and forward into the life and times of their Icelandic progeny; two of the redactions boast some 3,500 personal names and 1,500 place names. ${ }^{7}$ The factual lists are occasionally supplemented with narrative anecdotes, the importance of which, in the evolution of the Icelandic family saga, is generally acknowledged. ${ }^{8}$ It would appear that the earlier versions were shorter and the later ones longer, the result in part of the provision of fuller genealogical information and in part of the accretion of anecdotes. Of some interest from the point of view of open composition is the theory that Ari did not author a settlement book per se, but wrote numerous short notices or schedae that remained for his inheritors to gather into manuscript form. ${ }^{9}$

${ }^{6}$ For a summary of the textual problems, see the introduction to the Fornrit edition, pp. 1-cvi.

'Jakob Benediktsson, "Landnámabók" in Kulturhistorisk leksikon for nordisk middelalder (Oslo: Gyldendal, 1965).

${ }^{8} \mathrm{Of}$ some interest from the point of view of composition is Walther Heinrich Vogt's contention that the combination of Erzählungen and Berichte in Landnámabók evolved into classical saga style. See his "Die Frásagnir der Landnámabók," Zeitschrift für deutsches Altertum und deutsche Literatur, 58 (1920), 161-204.

${ }^{9}$ Halldór Hermannsson, The Book of the Icelanders (Islendingabók), Islandica, 20 (Ithaca, N.Y.: Cornell University Library, 1930), pp. 40-42, and his article "Ari Porgilsson fróði," Skirnir, 122 (1948), 20-22; also Einar Olafur Sveinsson's introduction to the Fornrit edition of Laxdcla saga, esp. p. xxxvi. 
From the purely descriptive point of view, Landnámabók is a polycentric work, a sequence of family clusters susceptible (as a comparison of versions shows clearly) of lateral amplification either in the form of further genealogical matter or anecdotes. Simultaneity in the broad sense is inherent in the format. The narrator's problem is how, on one hand, to be chronological within the cluster and, on the other, to correlate certain events in that cluster with events in other clusters; for the family chronicles do not exist in isolation, but interact and overlap with one another to the point where, in some cases, they are for all practical purposes inextricable. The solution is a rudimentary form of stranding. Persons are necessarily mentioned in connection with stories other than their own (e.g., the stories of the families into which they marry, or events in which they participate as minor figures). The cross-referencing formulas in the Sturlubók and Hauksbók redactions point either backward (er fyrr var getit , "as was mentioned before") or forward (sem enn mun sagt verða, "as is still to be told") to the "main" entry.

One of the longest and most colorful narrative passages in the Sturlubók redaction is the story of Auorr in djúpúoga (known in fuller form from Laxdola saga). Mentioned first in the list of Ketill flatnefr's children ( $S 13)$, she is put aside for some pages until her marriage to Oleifr inn hvíti brings her back onto center stage ( $S$ 95). After the deaths of her husband and son, Auor has a ship built in secret which she then sails to Iceland, taking with her twenty freedmen-dux femina facti. The narrator devotes a paragraph to the members of her retinue ( $S 96)$, chiefly Kollr (later to become Dala-Kollr), and Erpr, son of the Scottish earl Meldún, who together with his mother Myrgjol, a declassed Irish princess, continues to serve Auor faithfully even after manumission. After her arrival in Iceland and settlement at Hvammr, Auơr parcels out land to her retainers $(S$ 93) and arranges marriages for her children; in each case the person in question heads a descending genealogy. Finally, the narrator returns to Auor and tells the story of her death-feast and burial. Auor's "story" may be outlined thus:

$\mathrm{A}^{1}$ Auơr introduced as one of Ketill flatnefr's children. (Other portions of Landnámabók.)

$A^{2}$ Auơr marries Óleifr inn hvíti. He dies, leaving Auð̃r with a son, 
porsteinn, and a grandson, Oláfr feilan. Porsteinn is killed. Auơr has a ship made in secret and escapes with a large retinue.

$B^{1}$ Kollr is mentioned.

$\mathrm{C}^{1}$ Erpr and his mother Myrgjol are mentioned.

$A^{3}$ Auorr goes first to the Faeroes, then to Iceland. Spends the winter with her brother, then takes her own land and settles at Hvammr. She gives land to her retinue:

$D^{1}$ Ketill (land claim, genealogy)

$\mathrm{E}^{1}$ Hǫror (land claim, genealogy)

$F^{1} \quad$ Vífill (brief anecdote, land claim, genealogy)

$G^{1}$ Hundi (land claim)

$\mathrm{H}^{1}$ Sokkólfr (land claim, genealogical note)

$\mathrm{C}^{2}$ Erpr (land claim, genealogy) (Inserted genealogy)

$B^{2}$ Kollr (land claim, genealogy)

$I^{1} \quad$ Herjolfr (genealogy)

$\mathrm{J}^{1} \quad$ bórhildr (married by Aưor, genealogy)

$\mathrm{K}^{1}$ Ósk (married by Aữr, genealogy)

$L^{1}$ Oláfr feilan (reared by Auơr, genealogy)

$\mathrm{A}^{4}$ Auorr hosts a large feast, during which she dies.

There is no question of plot braiding here because all the "strands" are of a nonnarrative nature-mere lists of facts which take as a starting point Auor's generosity or matriarchal acts. The exception is the miniature entailed subplot concerning Erpr and Myrgjol:

Erpr hét leysingi Auð̃ar; hann var son Meldúns jarls af Skotlandi, pess er fell fyrir Siguroi jarli enum ríka; mơ̋ir Erps var Myrgjol, dóttir Gljómals Irakonungs. Sigurơr jarl tók pau at herfangi ok pjáði. Myrgjol var ambátt konu jarls ok pjónaơi henni trúliga; hon var margkunnandi. Hon varðveitti barn drottningar oborit, meðan hon var í laugu. Síðan keypti Aưor hana dýrt ok hét henni frelsi, ef hon pjónað̋i svá puríði konu porsteins rauơs sem drottningu. pau Myrgjol ok Erpr son hennar fóru til Íslands með Auði.

(Erpr was the name of a freedman of Auor. He was the son of Earl Meldún of Scotland, who was defeated by Earl Siguror inn ríki. Erpr's mother was Myrgjol, the daughter of the Irish king Gljómall. Earl Siguror took the two of them, mother and son, as war captives and enslaved them. Myrgjol was the servant of the Earl's wife, and she served her faithfully; she was clever in many things. She cared 
for the queen's unlegitimated child while she was at the baths. After that Auor bought her for a high price and promised her freedom if she would serve Purírr, the wife of Porsteinn the Red, as well as she had the queen. Myrgjol and her son Erpr went to Iceland with Auorr.) [Landnámabók, $S$ 96, $H$ 83]

The result of such insertions, whether they are narrative or report, is that Auor's story is not told consecutively but broken into parts. The dramatic account of her flight and settlement is separated from the equally dramatic story of her self-arranged funeral by several pages of nondramatic matter, just as the notice of her birth is separated from the story of her marriage by a long span of other settlement information. The patterns of interruption and suspension which lie at the center of the classical saga aesthetic are, in other words, implicit in Landnámabók, prompted by a concern with correct chronology and conditioned by the pluralistic nature of the subject matter.

Ágrip. Probably written by a Norwegian cleric toward the end of the twelf th century, Agrip is a summary in about thirty pages of some 250 years of Norwegian history. ${ }^{10}$ The Latin training of its author is apparent in the syntax and certain verbal mannerisms. The pace is too brisk to allow for the pursuit of any length of different sides of the action, but the scope and complexity give the broad impression of synchronic events:

En pá var Sveinn frá fallinn í Danmorko ok svá Knútr fapir hans í Englandi, ok réb pá fyrir Danmorko brópir Sveins, Horpaknútr at nafni, ok helt her á móti Magnúsi ok fundosk í Brenneyiom.

(At that time Sveinn had died in Denmark and likewise his father in England; and Sveinn's brother, whose name was Horoaknútr, was ruling in Denmark, and he launched a campaign against Magnús [of Norway] and they met on the Brenneyjar.) [chap. 36]

Unremarkable in themselves, such notices become, in later kings' saga tradition, dramatically fleshed out into fully simultaneous

${ }^{10}$ On Agrip, see Ellehøj, Studier, pp. 197-304; and Bjarni Aðalbjarnarson, Om de norske kongers sagaer, Skrifter utgitt av Det Norske Videnskaps-Akademi i Oslo, II, hist.-fil. kl., no. 2 (1936), pp. 1-54. 
narration. There is also a hint of open composition in such lateral extensions as the folktale-derived story of Snæfrior (chaps. 3-4). ${ }^{11}$ There exist a few verbal tags such as svá er sagt and cross-referencing phrases such as sem fyrr var sagt, but no actual transitional formulas.

Historia de antiquitate regum Norwagiensium. In the introduction to his history of the Norwegian kings (written ca. 1177$80),{ }^{12}$ Theodoricus, a Norwegian monk possibly trained abroad, outlines his narrative procedure:

Digressiones etiam more antiquorum chronographorum non inutiles, ut arbitramur, ad delectandum animum lectoris locis competentibus adjunximus.

(We have also added digressions in the appropriate places according to the custom of ancient writers, not ill-suited, as we think, to delight the mind of the reader.) [Prologue]

The form of digression Theodoricus uses is much like that of Jordanes (to whom he refers in chapter 17) and Paul the Deacon, whose use of the device is singled out for approval:

Paulus quoque Diaconus, monachus Cassinensis coenobii, qui conscripsit historiam pulcherrimam de Pannonia provincia, in qua multas utiles et non minus delectabiles fecit digressiones, pæne idem loquitur de Charybdis natura.

"The folktale origins of the Snæf rior episode are restated by Bjarni Aðalbjarnarson in his introduction to the Fornrit edition of Heimskringla, p. lix and note 3 . Jan de Vries, following Finnur Jonsson's observation of a Latinate phrase, argues for a Latin original; see his "Harald Schönhaar in Sage und Geschichte," Beiträge zur Geschichte der deutschen Sprache und Literatur, 66 (1942), 55-117 (esp. pp. 85-86). De Vries agrees with Finnur Jonsson and disagrees with Anne Holtsmark about the Latin original; see her "Om de norske kongers sagaer," Edda, 38 (1938), 145-64.

${ }^{12}$ On Theodoricus's Historia, see Ellehøj, Studier, pp. 175-96; Arne Odd Johnsen, Om Theodoricus og hans Historia de antiquitate regum Norwagiensium, Avhandlinger utgitt av Det Norske Videnskaps-Akademi i Oslo, II, hist.-fil. kl., no. 3 (1939), pp. 1-112; Jens Th. Hanssen, "Theodoricus Monachus and European Literature," Symbolae Osloenses, 27 (1949), 70-127; and Bjarni Guơnason, "Theodoricus og íslenskir sagnaritarar" in Einar G. Pétursson and Jónas Kristjánsson, eds., Sjötíu ritgerðir helgaðar Jakobi Benediktssyni, 2 vols. (Reykjavík: Stof nun Árna Magnússonar, 1977), II, 107-20. 
(Paul the Deacon, monk in Monte Cassino, who wrote the excellent history of the province of Pannonia, in which he made many useful and no less delightful digressions, gave nearly the same account of the nature of Charybdis.) [chap. 17]

Theodoricus's own digressions are for the most part of the standard "philosophical" sort. The event of Hákon's drowning occasions a long description of Charybdis, which shades into a passage on the Huns and ends with a pious quotation from Psalms (chap. 17). The narrative returns to local matters when, in chapter 18, news of Hákon's death reaches his uncle Knútr in England. Other digressions involve learned speculations on the age of the world, Charlemagne, ill-fated ambition, the progressive diminution in the size of men, and so forth-all effected by a conventional array of aphodoi clearly imitative of those used by Paul the Deacon, Adam of Bremen, or some similar practitioner of this "highly favored rhetorical figure": ${ }^{13}$

Sed ad nostra redeamus. (But we should return to our topic.) [chap. 5]

Sed revertamur ad nostra. (But let us return to our topic.) [chap. 8]

Sed regrediamur in Norwagiam. (But let us return to Norway.) [chap. 23]

Nos ista in medio relinquimus. (We leave these things in the middle.) [chap. 33]

But not every such phrase in Theodoricus's Historia involves a digressio ad aliud extra materiam (to refer again to the distinction drawn by Geoffrey of Vinsauf). At least two cases are sufficiently local to be classified as digressiones ad aliam partem materiae. The phrase "Hæc de his dicta sufficiant (But enough has been said about this)" concludes a short chapter on the activities of Pangbrandr in Iceland (chapter 12) and brings the narrative back

${ }^{13}$ Thorkil Damsgaard Olsen, "Kongekrøniker og kongesagaer," Norron fortallekunst: Kapitler af den norsk-islandske middelalderlitteraturs historie, ed. Hans Bekker-Nielsen, Thorkil Damsgaard Olsen, and Ole Widding ([Copenhagen]: Akademisk forlag, 1965), p. 49. 
to Oláfr's continuing conversion effort in Norway. More strikingly intramural is the following example:

Variis deinde conflictationibus inter se agentes Magnus et Sveino plura proelia gesserunt in diversis locis, quorum maxima ista fuerunt: apud Helganes unum, aliud apud Aros et non multa præterea. Sed quia longum est singulis immorari, transeamus ad cætera. Videns itaque Sueino, se non posse resistere viribus Magni, discessit a patria; quem insecutus rex cum classe applicuit in loco, qui dicitur Ourarsund.

(Then taxing each other with various conflicts, Magnus and Sven waged several battles in various places, of which the greatest were the following: one at Helgenes, the second at Aarhus, and not many besides these. But because it is tedious to dwell on particular events, let us pass on to other things. Thus Sven, seeing that he could not resist the power of Magnus, departed his homeland; the king, pursuing him with his fleet, hove into that place called $\emptyset$ resund.) [chaps. 24-25]

Evidently, Theodoricus was not bound by a strict definition of digression, but like his Latin-writing contemporaries could use it simply to mark a time dislocation within the matter. His history therefore documents not only an enthusiasm for the device in both the narrow and the broad sense, but also a nonconsecutive approach to narrative.

Historia de profectione Danorum in Hierosolymam. Preserved in the same manuscript as Theodoricus's Historia is the Profectio Danorum, a short chronicle, written some time before the death of Sverrir in 1202, about a Scandinavian crusade to the Holy Land. ${ }^{14}$ It is generally held to be of marginal literary or historical concern, but it is of some interest from the point of view of composition because of its fuller use of intramural digressions and aphodoi involving clear temporal dislocations and a concern with proper order. For example, after citing a long, impassioned

${ }^{14}$ On the Profectio, see Vegard Skånlund, "Profectio Danorum in Hierosolymam," in Kulturhistorisk leksikon for nordisk middelalder; and Eirik Vandvik, Om skriftet De profectione Danorum, Avhandlinger utgitt av Det Norske Videnskaps-Akademi i Oslo, II, hist.-fil. kl., no. 4 (1954), pp. 3-35. 
papal letter calling for the liberation of Jerusalem, the chronicler turns to matters in Denmark:

Hec et alia quamplurima pagina continebat apostolica, exhortans singulos, confortans uniuersos. Nunc autem ad ea, que in Dacia super hoc lachrymabili negotio gesta nouimus, uertamus articulum.

(This and many more things the pope's letter contained, exhorting the individual, encouraging all. But now let us turn the "article" [portion of the narrative] to those matters that we know transpired in Denmark concerning this lamentable business.) ${ }^{15}$ [chap. 3]

Somewhat later, a digression on the term "land of milk and honey" concludes with these words:

Non est tamen presentis occupationis mysteria perscrutari; sed ad narranda, que restant, reuocetur oratio. Porro uiri pretaxati ad sua peragenda negotia perseueranter insistunt, armamenta nauium colligentes.

(It is not, however, our present task to probe mysteries; let our discourse rather return to the telling of those matters which remain. The men already mentioned diligently pursue the business at hand, gathering the ships' gear.) [chaps. 6-7]

A description of an encounter between Sverrir and the Danes is similarly concluded:

Vt enim ea, que narrare gestio, luculentiori stilo ualeam indagare, superiori reincipiendium est exordio.

(So that I may be able to explore more clearly those matters I desire to relate, it is necessary to return to my previous point of departure.) [chap. 13]

The promised explanation has to do with the political state of affairs Sverrir inherited in Norway.

The first two-thirds of the Profectio are in effect a prelude in

${ }^{15}$ For a comparison of transitional formulas in Theodoricus's Historia and the Profectio, see Vandvik, Om skriftet De profectione Danorum, p. 16. 
which the would-be pilgrims travel about Scandinavia making preparations and gathering support for their cause. The crusade proper begins in chapter 15 , when they embark from Bergen in three groups: first the Danes, then Sven, then Ulf. At exactly its most dramatic phase, in other words, the account splits into three stories. The narrator's solution closely resembles classical saga stranding both in its composition and its use of verbal transitions. The passage may be outlined as follows:

A + B The Danes and Sven leave Bergen and go to an island, where they wait for Ulf. Dissension breaks out; the Danes depart, leaving Sven and his men in wait.

B + C Ulf arrives; he and Sven trade speeches; Sven and his men depart.

C After some time, Ulf departs and is carried to his destination by the same wind that drove the others off course. "Ad narrandum denique, quamquam rudi stilo et incomposita uerborum serie, quod cepimus, reuertamur (Let us then return to the narration which we began, though it be in rough style and disorderly sequence"chap. 18).

B Sven, having been abandoned by the Danes and no longer in company with the Norwegians "ut supra diximus (as we stated above)," foolhardily attempts an ocean crossing by himself. He sails night and day and encounters a long and violent storm that seems to spell doom; but at last it clears and they are saved. The following day, however, the storm breaks out again and causes a shipwreck. Many men are drowned, but some, by God's grace, are saved. (The narrator devotes an emotive chapter to the miraculous rescue of these crew members, and no more is heard of them.)

A "Ad illos iterum reuertamur, quorum mentionem supra factam lector inueniet (Let us return again to those whom the reader will find mentioned above"-chap. 22). The Danes encounter the same storm, but they jettison all their goods and reach Frisia, where they sell their ships and travel the rest of the way, via Venice, by land.

The braiding, such as it is, could easily be undone. Just as Ulf's story was told all in a piece, so could those of the Danes and Sven have been told consecutively. But by dividing and interspersing them, the narrator has dramatized (if rather lamely) a certain simultaneous idea: the north wind that spurred the Danes on their 
way is the same north wind that drove Ulf"s ship the "straight way" down the coast and the same wind that develops into the storm that shipwrecked Sven and brought the Danes to near ruin off the coast of Frisia. All this action occurs over the same Wednesday, Thursday, and Friday.

To the extent that it has been treated at all by critics, the Profectio Danorum has not fared well. Eirik Vandvik judged it to be a pupil's exercise: "The execution itself points in this direction: it is in a number of respects an immature work-bumbling in its composition, not infrequently deaf to the nuances of Latin words and phrases, and sprinkled with random learning." ${ }^{16}$ The question is whether the "pupil" invented this piece of parallel narration or drew on a model, and if the latter, whether the model was foreign or native. Whatever its other shortcomings, the Profectio Danorum contains a full-fledged example, complete with verbal apparatus, of simultaneous narration.

Historia Norwegia. The introduction of the Historia Norwegia concludes with the following words: ${ }^{17}$

Huc usque situm et circumstantias Norwegix ostendimus, nunc autem trifariam ejus habitationem exsequamur.

(Up to this point we have shown the setting and conditions of Norway, but let us now describe her three habitable regions.) [p. 76]

First comes a description of the coastal regions, ending with the formula:

Revertentes a maritimis transferamur ad montana.

(Turning from the maritime regions, let us pass on to the mountains.) [p. 80]

A brief paragraph on the highlands ends similarly:

${ }^{16}$ Ibid., p. 34.

${ }^{17}$ On the Historia Norwegia, see Ellehøj, Studier, pp. 142-74; Adalbjarnarson, Om de norske kongers sagaer, pp. 1-55; and Jens Th. Hanssen, Omkring Historia Norwegiae, Avhandlinger utgitt av Det Norske Videnskaps-Akademi i Oslo, II, hist.-fil. kl., no. 2 (1949), pp. 70-127. 
Peragratis montanis silvas Finnorum ingrediamur perscrutatum.

(Having explored the mountains, let us now enter the forests of the Finns to investigate them.) [p. 82]

From the Finnish forests the narrator looks west to the insular colonies:

Circumscriptis utcunque Norwegiæ finibus tendamus ad tributarias insulas, nam insulas, quæ adjacent Norwegiæ, præ multitudine nemo numerare potest.

(Having described the borders of Norway, however, let us turn to the tributary islands, for no one can count the islands which flank Norway because of their great number.) [p. 87]

This survey in turn is concluded:

Hactenus tributarias insulas carptim descripsimus; nunc vero qui reges Norwegiam rexerunt vel unde processerunt ad exponendum stilum vertamus.

(Thus far we have described the tributary islands one by one; but now let us turn our pen to relate what kings ruled Norway and whence they descended.) [p. 97]

At this point the narrator turns to the succession of kings, ending (apparently prematurely) with the arrival of Saint Olafr in Norway.

One of the immediate sources for the Historia Norwegia was Adam of Bremen's church history. ${ }^{18}$ But if Adam used aphodoi both to mark off sections of the narrative and as devices for internal digressions within the matter, the Historia Norwegia uses them only in the former sense. ${ }^{19}$ The royal history proper

\footnotetext{
${ }^{18}$ See Ellehøj, Studier, esp. pp. 146-61.

${ }^{19} \mathrm{Cf}$. the aphodos (clearly of learned origins) used by the First Grammarian to mark off the sections of that treatise: "Nú lyk ek hér umrờu raddarstafanna, en

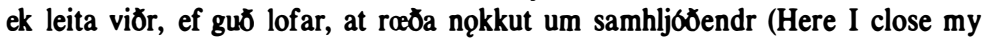
consideration of the vowels, and, God willing, I shall try to say something about the consonants)." From Einar Haugen, ed., The First Grammatical Treatise, Language Monograph No. 25 of the Linguistic Society of America, 2d ed. (London: Longman, 1972), pp. 22-23.
} 
(the last twelve pages) contains no such phrases and is in general linear, nondramatic, and nondigressive.

Hryggjarstykki. The special importance of Eirikr Oddsson's Norwegian history (ca. 1150 or 1170) lies in the fact that unlike such works as Ágrip and the Historia of Theodoricus it relied not on older sources but on the reports of contemporary witnesses. ${ }^{20}$ Hryggjarstykki is not extant as a separate work, but it is possible, by examining those portions of Morkinskinna, Fagrskinna, and Heimskringla which incorporated it, to make at least a rough assessment of its content and form. In general, Hryggjarstykki appears to display the brachial composition characteristic of early kings' saga tradition. The royal biography is not conceived as a static portrait, but as a dynamic sequence of interactions. Thus not only the king but also those with whom he interactssupporters and competitors-necessarily receive a measure of narrative attention. Many threads are advanced together with the main thread, and though they are seldom pursued long enough to be considered subplots, the larger pattern-the nervous alternation among focal points-suggests an incipient form of stranding. It would appear, for example, that Eirikr Oddsson wove together at some length the stories of Siguror slembir, Magnús inn blindi, and the Danish king Eiríkr with at least a rough degree of understood simultaneity as they converge and part. ${ }^{21}$ But there are no transitional formulas (nor are there elsewhere in Fagrskinna, although they appear with some frequency in Heimskringla and Morkinskinna), and one is left with an overall impression not of deliberate or artful plot weaving, but of a haphazard exposition, presumably conditioned by the nature of the sources and, of course, the events themselves.

Oldest Saga, Legendary Saga, and Styrmir's Saga of Saint Oláfr. Brief as they are, the six fragments of the Oldest Saga

${ }^{20}$ The most recent contribution on Hryggjarstykki is that of Bjami Gữnason, Fyrsta sagan, Studia Islandica, 37 (Reykjavík: Bókaútgáfa Menningarsjő̌s, 1978). See also Aðalbjarnarson, Om de norske kongers sagaer, pp. 156-69; Sigurסur Nordal, "Sagalitteraturen," Nordisk kultur, 8, pt. B (1953), 195-97; and Jan de Vries, Altnordische Literaturgeschichte, II, Grundriss der germanischen Philologie, 16, 2d ed. rev. (Berlin: de Gruyter, 1967), 233-35.

${ }^{21}$ See especially pp. 304-9 in Heimskringla; 345-49 in Fagrskinna; and 409-19 in Morkinskinna. 
(ca. 1200) permit certain conclusions about the form of the nowlost whole. ${ }^{22}$ The paratactic and scenic quality of the text reflects an established mode of anecdotal storytelling. The capacity for plot proliferation by means of entailment is documented in Fragment I with the story of Ásbjön selsbani. Ásbjorn breaks a royal prohibition on the transfer of grain and is caught and humiliated by the king's steward Porir selr; he seeks revenge by dropping in on a royal progress feast and decapitating Porir before the king's eyes. The king calls out for Ásbjorn to be captured and killed, but Skjalgr intervenes-here the fragment breaks off. Similarly, the anecdotes in Fragments II and III indicate a strong interest in the lives of the skalds-another rudimentary form of lateral expansion. Finally, there is a full-fledged stranding formula:

Nú skal par til taka, sem fyrr var frá horfit. Pá er Oláfr inn sænski var frá fallinn, pá tók Önundr Svípjő ok allt ríki eftir föður sinn.

(Now to take up what was left off earlier: After Oláfr inn sænski had fallen, Önundr took over Sweden and all his father's realm.) [p. 413]

The reference is missing, but the phrase itself indicates some degree of simultaneity.

If the Oldest Saga was once thought to be a predecessor of the Legendary Saga, they may now be regarded as variants. ${ }^{23}$ The latter is somewhat more compendious than the former, but they otherwise appear to conform to more or less the same scheme of composition. The Legendary Saga author's narrative fixation on the figure of the king betrays a hagiographic orientation (one of the chief differences between the Legendary Saga and the Separate Saga, and in turn between the Separate Saga and the Heimskringla versions of the Olafr biography, is the proportion of

\footnotetext{
22Jonna Louis-Jensen, “ 'Syvende og ottende brudstykke': Fragmentet AM 325 IV $\alpha$ 4to" in Opuscula, IV, Bibliotheca Arnamagnæana, 30 (Copenhagen: Munksgaard, 1970), pp. 31-60.

${ }^{23}$ See Jónas Kristjánsson, Um Fóstbræđrasögu (Reykjavík: Stofnun Árna Magnússonar, 1972), p. 167: "The texts of the fragments and the Legendary Saga are so closely related that the most obvious solution is to consider them one and the same saga." See also Louis-Jensen, "'Syvende og ottende brudstykke,"' pp. $59-60$.
} 
narrative devoted to the "other side"). ${ }^{24}$ Yet despite its generally unilateral quality, the Legendary Saga makes occasional excursions, by a process of entailment, into other matter-subplots that intersect, at some point, with the life of the king. Again, the story of Ásbjorn selsbani serves as an example. After his slaying of Porir selr (to continue where the Oldest Saga left off), Ásbjorn is made to await sentence; Skjalgr and Porarinn intervene on his behalf, and their efforts, together with a display of force on the part of Erlingr Skjalgsson, bring the king around. Ásbjorn is himself appointed steward, but shortly thereafter he breaks the terms and is sought out and killed. This last phase is told briefly in a coda paragraph:

Ferr nú Ásbjǫrn norơr heim fyrst ok segir Póri, frænda sínum, hver lykt er á varó. Hann segir svá, at ill var in fyrra fọr hans, en sjá var hálfu verri, er hann skyldi vera konungs præll alla ævi sína. Svá talar hann um fyrir honum, at hann ferr nú ekki norðan ok dvaldist nú heima. Konungrinn fréttir nú petta, at hann helt ekki pat, sem mælt var, sendir til menn at drepa hann.

(Ásbjorn now goes north to his home and tells Porir, his kinsman, how things have turned out. He says that bad as his first journey had been, it was not half as bad as this one, for he was now destined to be the king's thrall for the rest of his life. He declared to Porir that he would not go south, and so he stayed at home. The king now learns that Ásbjorn was not keeping to the agreement they made, and he dispatches men to kill him.) [Legendary Saga, chap. 49]

Ásbjorn's story hardly forms a self-contained subplot. Yet the very fact that it has been pursued to a certain extent for its own

\footnotetext{
${ }^{24}$ The shift from the unilateral account of Olaff's political downfall to a more balanced one is traced in Wolfgang Fleischhauer, Kalf Arnason: Die Berührungen zwischen Heldenlied und Königssaga (Cologne: Orthen, 1938); also, with special reference to hagiographic traditions, in my "Runzivals pattr, Njals saga, and Legendary Saga: A Structural Comparison" (Ph.D. dissertation, University of California at Berkeley, 1972), esp. pp. 77-169. If the Oldest Saga was similarly king-focused (as the fragments suggest it was), it, too, may be considered affected by hagiographic conventions. Cf. Louis-Jensen ("Syvende og ottende brudstykke," " p. 60): "In the NRA 52 fragments themselves there is nothing to suggest that the Oldest Saga contained any matter whatever of a legendary nature, and the burden of proof rests on those who see the Oldest Saga as a clumsy attempt to combine a model borrowed from foreign hagiography with Ari's historiographic principles." See also Kristjánsson, Um FóstbræOrasögu, pp. 151-72.
} 
sake, above and beyond its immediate relevance to the royal biography, is a significant harbinger of future developments in the evolving tradition. Like the skaldic subplots, Ásbjorn's will eventually assume the proportions of a self-contained pattr. The tendency toward plot proliferation is thus documented in this work from what Nordal called "the infancy of saga-writing." 25

At no point does the narrator of the Legendary Saga lapse, in prebattle or battle sequences, into full parallel narration, but rather alternates rapidly among the focal points in the manner of Hryggjarstykki-far from artful, but nonetheless indicating the inclination toward fragmentation and interruption. The aesthetic of suspense and delay is further suggested by the fact that of the two items added to his biography by the Legendary Saga author, one, the Kristni pattr, is divided and inserted in two parts (the other, a list of miracles, is attached as a sequel). There are numerous verbal tags throughout the saga (e.g., svá er sagt), and on those few occasions when the narrative actually divides (e.g., between the king and Dala-Guðbrandr in chapters 32-33) there are found phrases of the type Nú er frá pvi at segja. But there are otherwise no simultaneous formulas (the above-cited formula in the Oldest Saga does not appear in the Legendary Saga).

Styrmir's version of the Olaffr biography was widely used by later redactors, but, like Styrmir's other literary production, it no longer survives as a separate work. The only extant texts that can be ascribed to Styrmir with a fair degree of certainty are the "articles" preserved in Flateyjarbók. ${ }^{26}$ These give no evidence whatsoever of multi-ply composition or transitional formulas; on the contrary, they appear to be even more monothematic than the Legendary Saga or the Oldest Saga. It may, of course, be that the "articles" are not representative of Styrmir's other production (that being one reason they were segregated as "articles"). But the assimilated state of his other production (e.g., in the Great Saga) defeats any effort to amive at conclusions about Styrmir's compositional habits. ${ }^{27}$

${ }^{25}$ Nordal, "Sagalitteraturen," p. 201.

${ }^{26}$ Flateyjarbók, III, 237-48; Great Saga, II, 683-95.

${ }^{27}$ See esp. Sigurour Nordal, Om Olaf den helliges saga: En kritisk undersogelse (Copenhagen: Gad, 1914). 
Sverris saga. The first full-length biography of a contemporary king, Sverris saga is thought to have been at least begun by the Icelandic abbot Karl Jonsson (died ca. 1212), perhaps in consultation with the king himself. Just how much of the existing work can be ascribed to Karl (the so-called Grýla portion) is not known. ${ }^{28}$ What is clear, however, is that the middle part of the saga (ca. chapters 32-100) differs emphatically, in both its style and its composition, from the preceding part (the Grýla?) and, to a somewhat lesser extent, from the one following. The earlier part is almost wholly monothematic, whereas the following portion is thoroughly and richly stranded. Ludvig Holm-Olsen's description of the narrative technique between chapters 33 and 38 is worth quoting at length:

The narrative in these chapters is superbly composed. We are prepared for the coming battle and held in mounting suspense by being plunged alternately into Sverrir's camp and that of the enemy. We follow Sverrir, during the course of the evening, across the river Nio and then the Gaular, ostensibly in a direction away from Niơaróss. In the next chapter (34) we are in the town, among Erlingr's and Magnús's men, where a mood of insecurity and nervousness prevails because no one knows what Sverrir's plans are. "Now it is to be told of the Birkibeinar [Nú er at segja frá Birkibeinum]," says the author (chap. 35). They have arrived in the vicinity of the town in the first light of dawn. Sverrir dismounts at Feginsbrekka and delivers a speech to his men. It turns out that he wants to try an attack on Nið̌aross. We leave them on their way down from Steinbjörg, and the scene shifts again. Once more we find ourselves among Magnús's men (chap. 36), this time out on Eyrar, just as they catch sight of the Birkibeinar. We follow the hectic preparations right up to the point when Earl Erlingr marches out, at the head of his men, against the enemy. But the battle does not begin until the author has brought his readers back to Sverrir's army. Only after relating an episode involving a priest Ozurr, whom we shall soon meet again, does our author turn to the description of the battle. It is this method of unfolding the narrative-by revealing the events alternately from the point of view of one party and then the other-that is also employed

\footnotetext{
${ }^{28}$ See Ludvig Holm-Olsen, Studier $i$ Sverres saga, Avhandlinger utgitt av Det Norske Videnskaps-Akademi i Oslo, II, hist.-fil. kl., no. 3 (1952), pp. 7-104.
} 
so brilliantly in the account of the battle in Norafjgror from chapter 81 on. $^{29}$

Differences in form are reflected in the use of formulas. There are none up to chapter 36 , but many, including several elaborate ones, after that. Holm-Olsen, reviewing the occurrence of such phrases as Nú er at segja frá ("Now it is to be told of") and Nú er at segja nọkura atburði ("Now certain events are to be related"), concludes: "If it is so that [AM $3274^{\circ}$ ] represents the original form here, the text from chapter 36 to chapter 156 is set off by a characteristic set of introductory formulas." 30 There is, moreover, a slight but significant tendency for AM $3274^{\circ}$, presumably the most conservative of the manuscripts, to use firstperson-plural formulations where Flateyjarbók and Eirspennill give impersonal equivalents (or avoid them altogether.) ${ }^{31} \mathrm{~A}$ striking example is the following:

$\mathrm{Nu}$ munum ver segia noccora parta pa er gerouz i fundi peira iii. konunga er nu hefir aðr verit noccot af sagt verpr nu partil at taca er apr var fra horfit. at Birkibeinar reru ut fra landi.

(Now we will tell certain parts [of the events] which occurred in the encounter between the two kings, of which something has been said before. The story picks up at the point where it left off earlier, when the Birkibeinar rowed out from the shore.) [AM $3274^{\circ}$, chap. 91]

$\mathrm{Nu}$ er at segia nokcura atburði pa er gerduz i fundi pessa .ij. konunga. er par til at taka at Birkibeinar reyru vt a mot Heklungum.

(Now are to be told certain events which occurred in the encounter between the two kings. The story picks up where the Birkibeinar row out toward the Heklungar.) [Eirspennill, chap. 81]

Not only does Eirspennill show a preference for an impersonal construction (as opposed to the munum vér of AM $3274^{\circ}$ ), it uses the standard word atburðr instead of the bookish partr.

Of Sverris saga we may therefore say, first, that its middle

${ }^{29}$ Ibid., pp. 71-72.

${ }^{30}$ Ibid., p. 70.

${ }^{31}$ Ibid., pp. 68-71. 
portion is emphatically stranded and simultaneous in all the manuscripts and, second, that the version regarded as oldest is also the one in which the phrasing of the transitional formulas is so like the Latin aphodoi that they may be considered vernacular derivatives. The receptiveness of the Sverris saga author or authors to foreign influence, including Latin chronicles, is well known. That this receptiveness extended to composition seems clear from the phrasing of the transitions, among other reasons. One of the most sagalike narratives of the preclassical period, in other words, is also one of the most manifestly Latin-influenced.

Oddr's Saga of Óláfr Tryggvason. The first independent biography of Oláfr Tryggvason was written about 1190 by Oddr Snorrason, a monk of Pingeyrar. The Latin original is lost, but the surviving vernacular manuscripts are thought to be fairly accurate reflections of the translation made about $1200 .{ }^{32}$ On the basis of the manuscripts it may be determined that the translation was a standard, serviceable combination of single-ply and multi-ply narration, depending on whether the focus is on the king or the political matrix, and that this must reflect, in turn, the formal organization of the matter in the Latin original. Some question may be raised about the originality of the many transitional formulas in AM $3104^{\circ}$, however, for they are often missing or seriously altered in Stockholm $184^{\circ}$, as shown by the following examples:

$\operatorname{AM} 3104^{\circ}$

Stockholm $184^{\circ}$

$\mathrm{Nu}$ er par til at taca at Hakon j. heyrir micla frego af morgum orrostum.

(Now to pick up where Earl Hákon hears of the great fame [Olaffr won] in many battles.) [chap. 19]

par er til at taca at ipann tima reð Noregi Hakon j. Sigurpar s. er fyrr var fra sagt.
Hakon iarl heyroe mikla frego at Olafi ok orrostvm hans.

(Earl Hákon heard of Oláfr's great fame and of his battles.) [chap. 13]

Ok i pann tima reð Hakon iarl Sigurðar s. Noregi er fyr var fra sagt.

\footnotetext{
${ }^{32}$ See Aбalbjarnarson, Om de norske kongers sagaer, esp. pp. 55-85; also Olafur Halldorsson, "Olafs saga Tryggvasonar," in Kulturhistorisk leksikon for nordisk middelalder.
} 
([The story] is to be taken up at that time when Earl Hákon Siguroarson was ruling Norway, as was said before.) [chap. 18]

Nu er pat pessu næst at segia. at pa er aleið æfi Hakonar j....

(Now the next thing to tell is that when Hákon's life was drawing to a close....) [chap. 20]

Pat viliom ver oc rita, at a peim $v$. arum er Olafr konungr reð Noregi...

(We want also to write that during the five years when King Olafr was ruling Norway...) [chap. 63]
(And at that time Earl Hákon Siguroarson was ruling Norway, as was said before.) [chap. 12]

En er a leið̌ æfi Hakonar iarls.... (And when Earl Hákon's life was drawing to a close....) [chap. 14]

pat er sagt meðan 0 . konungr Tryggva s. var konungr at Norege ...

(It is said that while King Olafr Tryggvason was king in Norway...) [chap. 51]

In light of these differences, it is hard to know whether the first translation had transitional formulas, much less whether the Latin original had aphodoi, at the corresponding junctures. (If Oddr, as is supposed, had a copy of Theodoricus at hand, he was well acquainted with the techniques of digression and the figure of the aphodos.) $)^{33}$ The versions do agree, however, in their use of parallel stories; and whether accompanied by formulas or not, this proliferation may be assumed to derive from the original vita.

Gunnlaugr's Óláfs saga Tryggvasonar. The case of Gunnlaugr Leifsson is more difficult than that of his monastic brother Oddr but at the same time potentially more rewarding. Shortly after Oddr, Gunnlaugr wrote another, expanded version, also in Latin, of the life of Olafr Tryggvason. The saga no longer exists in the original, though portions of the Icelandic translations were incorporated in the Longest Saga of Oláfr Tryggvason. If we rely on Bjarni Aðalbjarnarson's identification of these portions, restricting our attention to passages on which the redactions agree, we may make the following observations. ${ }^{34}$ First, the wide-ranging 
focus, the narrative detail devoted to minor figures, and the inclusion of long bættir leave little doubt as to Gunnlaugr's inclination toward copiousness and digressiveness. Second, the frequent use of such transitional phrases as the following suggests simultaneous narration: ${ }^{35}$

AM 61 fol.

Flateyjarbók

$<$ A $>$ peim sama tíma sem nv var aőr fra sagt. var pat dæmt a sam kvamu af heraơs mỏnnum at fyrir sakir sultar ok sva mikils hallæris ...

(At the same time, as was told earlier, it was determined at a meeting of the men of the district that on account of hunger and such great famine...)

$\mathrm{N}<\mathrm{V}>$ skal vikia ræounni til peira frasagna er pat sanna at Olafr konungr hafi lifs a brott komiz or bardaghanum pa er Ormrin var vnninn.

(Now [we] shall turn the discourse to those accounts alleging that King Olalfr has escaped with his life from the battle in which the [ship] Ormr was captured.)
A peim sama tima sem nu uar adr fra sagt uar pat dæmt a samkuomu af heradsmonnum ok firir saker hallæris ok suo mikils sulltar...

(At the same time, as was told earlier, it was determined at a meeting of the men of the district that on account of famine and such great hunger...)

Nv skal uikea rędunne til peirra frasagna er pat sanna er Olafr konungr hafi a brott komizst or bardaganum a peirre somu snekkiu sem fyrr var getith.

(Now [we] shall turn the discourse to those accounts alleging that King Olafr escaped from the battle on the same ship that was mentioned before.)

The originality of at least a few such formulas would seem to be guaranteed by the fact that they appear not at the beginning or end but embedded in the middle of passages attributed to Gunnlaugr and, moreover, that they play a functional role in the composition. If this is so, they may be vernacular renditions of Latin aphodoi. A third point is that also embedded within passages ascribed to Gunnlaugr are numerous cross-referencing

${ }^{35} \mathrm{AM} 61$ fol passages from chapters 226 and 267; Flateyjarbók passages from chapters 346 and 393. 
phrases (sem sagt mun verða "as will be told [later]," sem áðr er getit "as was mentioned before," sem fyrr var sagt "as was told earlier"). These too may be the compiler's insertions; but if they are Gunnlaugr's own, they confirm the impression that his saga was richly stranded. There is, finally, the authorial reflection ascribed to Gunnlaugr (see p. 36 above):

Now it is not to be wondered at that many of the tales and stories written here seem not to belong to the saga of Olafr Tryggvason. For just as running water flows from various sources yet all comes together in a single place, so, in like wise, do all these stories from various sources have a common goal-to clear the way for those events which concern Olaffr Tryggvason and his men, as will become apparent in what follows.

The existence of a comparable metaphor in a different connection in the Jóns saga helga ascribed to Gunnlaugr would seem to confirm the attribution to him of the "network of streams" image and also to suggest that it may be a religious conceit. ${ }^{36}$ But of more concern than the metaphor, in this context, is the first sentence, the tone and inclusion of which must be taken to indicate that the composition of Gunnlaugr's Latin biography of Olaffr Tryggvason was more copious and fragmented than was considered customary by the aesthetic standards for religious biography in the late twelfth century. Moreover, by retaining the note in the Longest Saga, the compiler has generalized the sense of the original to the larger encyclopedia and so maintained the continuity of the stylistic tradition.

Fagrskinna. Like its predecessors in the kings' saga tradition, Fagrskinna (Norwegian, 1220s) casts its net broadly, taking in political developments not only in Norway and Denmark, but also in the North Atlantic colonies, including England. ${ }^{37}$ The composition is undistinguished, consisting in the main of synoptically told events laid end to end in time (litlu siðarr "a little later," eptir

${ }^{36}$ Aðalbjarnarson, Om de norske kongers sagaer, esp. p. 104.

${ }^{37}$ On Fagrskinna, see ibid., pp. 173-87; de Vries, Altnordische Literaturgeschichte, II, 282-85; and Gustav Indreb , Fagrskinna, Avhandlinger fra Universitetets Historiske Seminar, 4 (Oslo: Grøndahl, 1917). 
petta "after that," um haustit eptir "the following autumn," pessu næst "thereupon"). As Gustav Indrebø said, "The author's strength lies in holding firmly to certain main themes-a single thread. He follows straight lines, as it were, without digressions.... The artful braiding of many threads is not his style." 38 The rare efforts to apprehend parallel events are, like the following one, wooden:

EiRikr lagð̌e pa undir sec Noregh sva sem aðr var sagt. oc pæir .ii. brœơr varo iarlar oc var Eirikr rikare. han atte Gyðu dottor Svæins Dana konongs. pæira sunr var Hacon. Eirikr var hærmaðr mikill mikla æfe oc langa. oc allra manna sigrsælastr. hann gerðe frægðar værk pat at hann drap Tið̌nda-Skofta er fyrr var ritat.

(Eirikr conquered all of Norway, as was told before. And of the two brothers who were earls, Eiríkr was the more powerful. He was married to Gyða, daughter of the Danish king Sveinn; their son was Hákon. Eiríkr was for a very long period of time a great warrior, and of all men he was the most successful in battle. He accomplished the famous deed of killing Tíðenda-Skopti, as was written before.) [chap. 24]

What stranding there is conforms to this pattern: nonscenic notices correlated by means of cross-referencing formulas. Apart from these phrases, the only noteworthy formula is

pa urou pau tið̌endi er að̌r var til visat. at peir funnuz Magnus konongr oc HaRalldr faor broðer hans.

(Then those events occurred which were referred to earlier, in which King Magnús and Haraldr, his uncle, met.) [chap. 44]

In fact, this retrieval phrase is gratuitous, because the meeting in question is immediately adjacent (it comes at the end of the preceding chapter). We may suppose that there was such a formula in Fagrskinna's immediate source, an earlier version of Morkinskinna. The extant version of Morkinskinna, however, indicates the transition with this switch: 
Nv er par til sogo at taca er fyr var fra horfit er peir finaz iDanmorc M. konvngr oc Haralldr foporbropir hans.

(Now there will be taken up in the saga what was put aside earlier, when King Magnús and Haraldr his uncle meet in Denmark.) [chap. 5]

This, of course, is standard saga phrasing, whereas the Fagrskinna formulation is Latinate in tone (cf. "Ad illos iterum reuertamur, quorum mentionem supra factam lector inueniet (Let us return again to those whom the reader will find mentioned above"-Profectio Danorum). It is hard to know whether the Fagrskinna author has retained or substituted a bookish phrase to mark this new story phase, but in either case it is symptomatic of the conservatism of the work as a whole. Despite its length, Fagrskinna is very much in the synoptic tradition, having much more in common with Ágrip and Hryggjarstykki than with Morkinskinna, Sverris saga, or the Legendary Saga.

Morkinskinna. In its present form, Morkinskinna (Icelandic, ca. 1220) marks a sharp departure in the kings' saga tradition. If Fagrskinna, as Ker comments, attempts to "restrict and select and give form to the material of tradition," Morkinskinna tends outward, making "large circuits and sweeping in all sorts of reminiscences and tales." 39 To the bare bones of Norwegian history have been added numerous anecdotes and whole pattir: porsteins páttr Hallssonar, Hreiðars páttr heimska, Halldórs páttr Snorrasonar, Auðunar páttr vestfirzka, among othersseveral of which bring Icelandic matter into the Norwegian sphere. Certain unevennesses of style, composition, and authorial attitude have led to the speculation that at least some of these subplots were not original but added at a later stage. ${ }^{40}$ Yet the lively presentation and the scenic quality both in the "digressions" and the "main topic" point to an accomplished narrator who, in Turville-Petre's words, "could tell many secrets about the history of Icelandic literature." 41

${ }^{39}$ W. P. Ker, "The Early Historians of Norway," Collected Essays, II (London: Macmillan, 1925), 150.

${ }^{40}$ Að̆albjarnarson, Om de norske kongers sagaer, pp. 135-73.

${ }^{41}$ Turville-Petre, Origins, p. 217. See also de Vries, Altnordische Literaturgeschichte, II, 280-81. 
All this matter is, or appears to be, knotted to the larger structure by the verbal apparatus of stranding: such phrases as "Nv er par til sogo at taca er fyr var fra horfit (Now to pick up a line of the saga that was set aside earlier)," "Nu er par enn til ath taka (Now to take up [this matter] once again)," "nv er at nefna mann er het Ivar huiti (now to name [i.e., bring into the saga] that man called lvarr hvíti)," and "oc lycr nv her at sinni fra Haconi i. oc Haralldi konungi (And now [let us] stop telling here of Earl Hákon and King Haraldr for the time being)." But there is a certain disparity between these verbal promises, as it were, and the actual composition of the matter. The formula "nv er par til sogo at taca er fyr var fra horfit (Now to pick up a line of the saga that was set aside earlier)" refers (as does its counterpart in Fagrskinna) not to a long-suspended action, but to the immediately preceding paragraph. The matter is conceived in lines, but the lines are not pursued at length, are not subject to a systematic alternation, and are not synchronized to the point where it is possible to speak of simultaneous narration. The sense of concurrence is clear enough, but the haziness of the short-term chronology defeats any effort to uncover an underlying time scheme.

Despite its shortcomings, Morkinskinna stands on the threshold of classical saga narrative. The delight in multiplicity, the unrolling of subthemes which then come back to and connect with the main topic, and the abundant use of conventional transitional phrases in the process-all these prefigure the aesthetic, if not the precise form, of the Icelandic family sagas.

The Great Saga of Saint Óláfr (Stockholm $\left.24^{\circ}\right)$. Stockholm 2 $4^{\circ}$ is the oldest preserved manuscript of the so-called Great Saga (or Separate Saga), a work in a later and shorter version included in Heimskringla. The Great Saga, then, belongs properly to the classical kings' saga tradition. But because it marks the culmination of a long development and because it relies heavily on earlier versions of the Olafr biography (particularly that of Styrmir), it will be briefly considered in its preclassical context.

The greater length of this version of the Olafr biography is largely accounted for not by significant additions to matter actually concerning the king, but by the inclusion of greater numbers of longer and more elaborate extensions into "other" matter. It 
departs in this respect from the Oldest and Legendary sagas, which, despite their occasional outward branchings, remain strongly king-focused in a manner reminiscent of traditional hagiography. The Great Saga is compositionally more akin to Morkinskinna, the middle portion of Sverris saga, and even the monkish sagas of Olafr (Oddr's certainly and Gunnlaugr's probably) than it is to its immediate predecessors. Focus is not exclusively on the king, but distributed among the many minor figures, both at home and abroad. It straddles, in other words, the border between biography and social or political narrative.

The processes of expansion and assimilation of this lateral matter are best seen in that venerable element of the Olafr tradition, the story of Ásbjǫrn selsbani. Ásbjorn's story was incompletely told in the Oldest Saga, but we may gauge by the narrative pace in the existing portion that it might have occupied two pages. In the Legendary Saga it occupies six pages and is told all of a piece. In the Great Saga it assumes the proportions of a miniature saga, occupying some eighteen pages, of which the last three consist of a full, dramatic account of the bloody death of Ásbjorn at the hands of the king's henchmen-an event related only cryptically in Legendary Saga. ${ }^{42}$ But more significant than the dilation of the matter per se is the fact that it is divided into two parts. Chapters 102-8 relate the conflict part of the story (how Ásbjorn violated the grain ban, was caught and humiliated by the king's steward, killed the steward in retribution, was captured and released and, upon appointment to the vacant stewardship, sent home), and chapter 112 tells the outcome (how he was sought out and killed).

\footnotetext{
${ }^{42}$ For a recent discussion of the evolution of the Asbjorn story-in particular its political dimension as it relates to the story of Porir hundr-see Ingebjørg Sogge, Vegar til eit bilete: Snorre Sturlason og Tore hund (Trondheim: Nordisk Institut, 1975), esp. pp. 31-37. There is an extensive literature on the evolution of the kings' sagas. Works that have some bearing on narrative developments include Sigurour Nordal, Om Olaf den helliges saga; the same author's Snorri Sturluson (Reykjavík: B. Porláksson, 1920; Toralf Berntsen, Fra sagn til saga. Studier $i$ kongesagaen (Oslo: Gyldendal, 1923); Siegfried Beyschlag, Konungasögur. Untersuchungen zur Königssaga bis Snorri. Die älteren Übersichtswerke samt Ynglingasaga, Bibliotheca Arnamagnæana, 8 (Copenhagen: Munksgaard, 1950); Gustav Storm, Snorre Sturlassöns historieskrivning. En kritisk undersogelse (Copenhagen: B. Lunos bogtrykkeri, 1873); and Hallvard Lie, Studier $i$ Heimskringlas stil, Avhandlinger utgitt av Det Norske Videnskaps-Akademi i Oslo, II. hist.-fil. kl., no. 5 (1936), pp. 7-136.
} 
But between the conflict and the outcome are inserted three quite different themes: one telling of Olaffr's ongoing conversion efforts (chap. 109), one telling how Olaffr settles in for the winter at Trondheim and how Einarr pambarskelfir goes to England and then to Rome (chap. 110), and one telling how Alfhildr, the king's mistress, becomes pregnant and gives birth to Magnús inn góxi (chap. 111). What is told, in the Legendary Saga, as a single lateral digression is thus in the Great Saga a full páttr that has been inserted in two parts, the intervening matter consisting of ongoing themes to be resumed at a later point. The particular value of the Asbjorn story is that it documents the developmental stages between narrative digression and full narrative stranding.

The Great Saga uses discontinuous and continuous retrieval with equal ease, the choice depending on the nature of the matter. The switch between chapters 111 and 112 is discontinuous (there is about a year's lapse), probably for the reason that Ásbjgrn's life between the moment he returns home and the time he faces the king's henchmen is of no particular narrative interest. Where both actions are of interest, the narrator renders them both, using the full array of verbal devices to do so. The beginning of chapter 62 ("Nv er par til mals at taca er peir menn como til Raugnvallz iarls er Ingigeror konungs dottir oc pau Hialti haufơv sent austan [Now the story picks up at the point where those men whom Ingigeror, the king's daughter, and Hjalti had sent from the east came before Earl Rognvaldr]') retrieves a line suspended, with no gap in time, some seven pages earlier (chap. 55). ${ }^{43}$ The beginning of chapter 71 ("Nv er par til mals at taca er aor var fra horfit at Olafr konungr enn digri for brvðferð [Now to pick up a line of the story set aside earlier, in which King Olaffr inn digri went on his bridal journey]') retrieves a line suspended, with no gap in time, about twelve pages earlier (chap. 65). There is even simultaneous alternation within the páttr of Ásbjorn selsbani: the first line of chapter 108, "Nv er par til mals at taka er fyr var fra horfit er peir Erlingr oc Scialgr son hans gerðv rað sin vm petta vannkveði (Now to take up a line of the story suspended earlier, in which Erlingr and his son Skjalgr made their plans regarding this diffi-

\footnotetext{
${ }^{43}$ Other manuscripts add to this phrase the words "er fyrr var frá horfit"
} ("which was set aside before"). See Great Saga, p. 160, note. 
culty)," refers back to the end of chapter 106 ("Siðan hafaz peir feðgar orð við̄; segir pa Scialgr Erlingi allan atburð vm vig Selporis [After that the father and son discussed this; Skjalgr then told Erlingr the whole story of Selporir's slaying]"). In other words, the story splitting incipient or latent at this point in the Oldest and the Legendary sagas is fully realized in the Great Saga.

It is in the Great Saga that the formula by which Olrik set so much literary stock is first attested:

Nv fer tvennvm savgvnom fram oc scal par nv til taca sem fra var horfit. oc fra pvi var sagt er Olafr konungr Harallz son hafôi frið gørt við Olaf Svia konung. oc pat at Olafr konungr for pat svmar noror til Prandheims.

(Now the two stories proceed together, and [we] shall pick up where [we] left off before, where it was said that King Olaffr Haraldsson had concluded a peace with King Olafr Svíakonungr, and that King Oláfr went north that summer to Trondheim.) [chap. 90]

The two stories in question are the so-called Orkneyinga saga and the ongoing history of Olaffr's Norwegian regency. In chapters 79-80 Oláfr concludes a peace with Óláfr Svíakonungr and goes to Trondheim (strand 1). The narrator then shifts to the Orkneys (strand 2), giving first a thumbnail historical orientation and then an account, itself stranded, of the political strife among the earls there. Only when this strand is advanced to the present moment of the other strand-that is, at the point when Olafr went to Trondheim after the settlement with Olaffr Svíakonungr-does the narrator shift the focus back and knot the two stories together with the "split saga" formula. The synchrony is both full and sweeping, involving a period of some twenty-five years (ca. 9951019). With this plot braiding we have arrived at complete narrative stranding or interlace. The "brilliantly gifted and autonomous narrator" of the Great Saga may fairly be considered the first "classical" narrator in the kings' saga tradition. ${ }^{44}$

44Damsgaard Olsen, “Kongekrøniker og kongesagaer,” p. 67. 


\section{Literary Features}

If stranded composition is an old feature in Norse tradition, we might expect to see some evidence of it in the earliest vernacular histories (Íslendingabók, Ágrip, Hryggjarstykki). But we do not find it there, even at those junctures where it would seem a likely and appropriate solution. Even though these early texts embrace an intrinsically complex subject matter, they stay for the most part close to the main theme and avoid or give only cursory treatment to minor themes-themes that in later works (e.g., Morkinskinna) are developed into fully dramatic subplots. The reluctance of the early historians to include historical marginalia in their accounts (we may assume that they knew considerably more than they wrote down) is a comment on their idea of what constituted a proper history-an idea that appears not to include lateral expansion or the scenic realization of the matter. Both narrative tendencies exist, to be sure (in Hryggjarstykki in particular), but when they occur they stand out as exceptions or lapses, not as normal procedure. Even Landnámabók, which as a formal construction lacks a main theme altogether but consists exclusively of minor themes, is oddly strict about keeping its family histories separate, telling consecutively stories that are understood as happening at the same time and depicted as interlocking in later versions. Again there are exceptions: stories are sometimes cross-referenced or on rare occasions interspersed. But such examples are too few and too rudimentary to qualify as stranded narration in the classical sense. The first vernacular histories document a concept of narrative that is brief, synoptically told, monocentric (with the exception of Landnámabók), and straightforwardly ordered. Insofar as the "lapses" tend in the direction of plot complication and the scenic mode, they seem to indicate an impatience with these restrictions. But the fact that they are exceptional, together with the fact that they in no sense constitute a consistent artistic solution, leads to the conclusion that the classical notion of composition is at most nascent at this early stage.

Latin prose is another matter. Like the European historians who stood as their models, the unknown authors of the Historia Norwegiæ and the Historia de profectione Danorum in 
Hierosolymam, and, above all, Theodoricus in his Historia de antiquitate regum Norwagiensium make abundant use of digression, not only in the strict sense (to bring in external matter) but also in the broader sense (to move about within the matter), using, in both cases, the figure of the aphodos to effect the transition. The first example in Norse tradition of the explicit and sustained use of simultaneous narration for dramatic effect, complete with transitional formulas, comes from the Profectio Danorum. The fact that aphodoi are used interchangeably for digressions proper and lateral digressions is of fundamental importance, for it indicates that the two were equated in the minds of the early historians. This obvious point has been missed by modern scholars, whose narrow definition of the device may correspond with classical notions but is out of tune with actual medieval practice as it is represented both in the rhetorical treatises and in the texts themselves. To single out the philosophical sort of digression and declare that its rarity in the classical sagas proves that their authors repudiated the Latin model is to misunderstand what digression meant and how it was used by the medieval Latin chroniclers. For them, the unrolling of side themes was no less a form of digression than the insertion of abstract speculations or far-fetched analogies. From the point of view of literary history, the former category is much the more significant, for as a specifically medieval "improvement" it points up a larger drift in the literary taste of that period, the clear direction of which in Norse tradition is toward the entailed narrative of the Icelandic sagas.

Fortunately, the link between Latin writings and classical saga practice is documented. It consists of two groups of hybrid texts: the translations into Norse of the royal biographies written originally in Latin and the early biographies written in the vernacular under the immediate influence of Latin models. The first category includes Oddr's and Gunnlaugr's lives of Oláfr Tryggvason, written first in Latin and composed, as nearly as we can tell, along Latin lines (Gunnlaugr's probably to a greater degree). The translation of such works as these involved more than a shift of language; it gave vernacular form to Latin digressiveness, and it invented or adapted from native stock a set of transitional phrases answering to the Latin aphodoi (the oldest wordings of the Norse phrases point firmly toward a Latin derivation). The second cate- 
gory includes the Legendary Saga and Sverris saga (especially its highly digressive middle portion, the transitional phrases of which, once again, have a distinctly Latin flavor). The dependence in varying degrees of these works on learned style and subject matter has long been recognized. What has not been sufficiently appreciated, however, is the extent to which their specific patterns of composition were also influenced by Latin practice. Like their Continental counterparts, these authors were quick to use the digression ad aliam partem materiae as a means of entailing the lives and activities of lesser characters onto the main theme and so to develop the social and political dimensions of the biography. That this type of composition was still in the formative stages at this point is suggested by the unevenness of its use from text to text (in sharp contrast with the relative uniformity of classical practice). That it is associated with foreign literary practice is suggested by the residue of Latin phrasings.

These two groups of texts may thus be said to form a "Latin connection" - $a$ transitional phase in which the naturalization of a foreign narrative mode is under way but not yet complete. Once appropriated into the vernacular, the digressive mode established itself and evolved quickly on its own terms. Morkinskinna is digressive to an unprecedented degree, extending the device beyond the single biography to a succession of reigns and so realizing, in a way that the earlier synoptic histories did not, the dramatic potential of political history. With the Great Saga, the "vernacularization" is for all practical purposes complete: narrative digression has become narrative stranding, and aphodoi have become the ubiquitous and standard verbal formulas of classical saga prose. As in the Icelandic sagas, the procedure is so fluently handled that its foreign origins are no longer identifiablealthough even in the family sagas one encounters occasional uses of digression proper (e.g., in Njáls saga), which serve to remind us that Latin composition was still a viable model for Icelandic writers even at this late stage. ${ }^{45}$

\footnotetext{
${ }^{45}$ The often-mentioned digressions of Fóstbroeðra saga may be considered stylistic rather than structural, though equally associated with Latin practice. Jonas Kristjansson dates the saga to the late thirteenth century and views the "digressive" versions as more original (Um Fóstbræorasögu, esp. pp. 55-96 and 292-307).
} 
This model of development permits us to distinguish more precisely the oral from the literary layer of saga narrative-the former being those features that, because they have no immediate counterpart in early Latin sources but are on the contrary associated with folktelling patterns, may be safely assumed to represent "native" narrative tradition. As oral features may be counted, in addition to the language itself, the smaller denominations of plot: scenes, episodes, and pættir. Scene is the smallest particle of story and may be defined in strictly formal terms as a tripartite "paragraph" consisting of a dramatic encounter preceded by a narrative preface and followed by a narrative conclusion. ${ }^{46}$ The following scene from Grettis saga (chapter 41 ) is a typical example. The preface establishes time, place, characters, and situation; the dramatic encounter consists of an exchange of dialogue (here a rather long conversation between Grettir and his brother Porsteinn); and the conclusion tells how the encounter comes to an end and the participants part ways.

[Preface:] Nú var Grettir með Porsteini, pat sem eptir var vetrarins ok fram á várit. pat var einn morgin, er peir braðor, porsteinn ok Grettir, lágu í svefnlopti sínu, at Grettir hafơi lagit hendr sínar undan klæðunum. Porsteinn vakð̋i ok sá pat. Grettir vaknaði litlu síðar. [Dramatic Encounter] bá mælti Porsteinn: "Sét hefi ek handleggi pína, frændi," sagði hann, "ok pykki mér eigi undarligt, pó at mǫrgum verơi pung hogg pín, pví at einskis manns handleggi hefi ek slíka sét." "Vita máttir pú pat," sagði Grettir, "at ek mynda ekki slíku til leiðar koma, sem ek hefi unnit, ef ek væra eigi allknár." "Betr betti mér," segir Porsteinn, "pó at væri mjórri ok nokkuru gafusamligri." Grettir segir: "Satt er pat, sem mælt er, at engi maðr skapar sik sjálfr. Láttu mik nú sjá pína handleggi," segir hann. Porsteinn gerơi svá; hann var manna lengstr ok grannvaxinn. Grettir brosti at ok mælti: "Eigi parf at horfa á petta lengr; kræekt er saman rifjum í pér, ok eigi pykkjumk ek slíkar tengr sét hafa, sem pú berr eptir, ok varla ætla ek pik kvenstyrkvan." "Vera má pat," sagð̋i porsteinn, "en pó skaltu pat vita, at pessir inir mjóvu handleggir munu pín hefna, ella mun pín aldri hefnt veróa." "Hvat má vita,

${ }^{46}$ See Carol J. Clover, "Scene in Saga Composition," Arkiv för nordisk filologi, 89 (1974), 57-83; Lars Lönnroth, Njals Saga: A Critical Introduction (Berkeley: University of California Press, 1976), esp. pp. 42-101; Richard F. Allen, Fire and Iron: Critical Approaches to Njáls saga (Pittsburgh: University of Pittsburgh Press, 1971), esp. pp. 57-75. 
hversu verơr um pat, er lýkr?" segir Grettir, "en allólikligt bykki mér pat vera." Eigi er pá getit fleira um viơrtal peira. [Conclusion:] Leiơ nú á várit; kom Grettir sér í skip ok fór út til Íslands um sumarit. Skilou peir breơr meơ vináttu ok sáusk aldri síðan.

([Preface:] Now Grettir stayed with Porsteinn through the rest of the winter and on into spring. One morning, when the brothers Porsteinn and Grettir were lying in the sleeping loft, Grettir put his arms out from under the bedcovers. Porsteinn was awake and saw this. After a while, Grettir woke up. [Dramatic encounter:] Then porsteinn spoke: "I've been looking at your arms, kinsman," he said, "and it doesn't surprise me that your blows seem heavy to many, for I have never seen arms like that on any man." "You might have guessed," said Grettir, "that I could never have accomplished what I have if I hadn't been fairly rugged." "It would seem better to me," says Porsteinn, "if your arms were thinner and somewhat luckier." Grettir says: "It's true, what they say, that no man creates himself. Now let me see your arms." Porsteinn obliged; he was an extremely tall man and lankily built. Grettir smiled at the sight and said: "I don't need to look any longer. Your ribs are all hooked together, and I don't think I've ever seen a set of arms more like tongs, and I doubt you have the strength of a woman." "That may be," said Porsteinn, "but you should know that if your death is avenged at all, it will be by these skinny arms of mine." "What can we know about how things turn out in the end?" says Grettir. "But I can't say that seems very likely to me." No more of their conversation is recorded. [Conclusion:] Now the spring passes. In the summer, Grettir gets aboard a ship and sails to Iceland. The brothers had a warm parting and never saw each other again.) [chap. 41]

It is not only the anecdotal quality of scenes such as this one that points to an origin in oral prehistory; it is the persistence of the fixed form in Norse narrative from the outset and over the generic range-including, significantly, the translated sagas, where a comparison with the original shows how the Norse redactors regularly add, delete, and reorder material in accordance with the tripartite template. ${ }^{47}$ Although such scenes as the arm compari-

${ }^{47}$ The "scenifying" process is particularly clear in Karlamagnús saga, in certain of the riddarasogur (e.g., Parcevals saga), and, as Dietrich Hofmann's analysis suggests, in the early translations of saints' lives. See his "Vers und Prosa in der mündlich gepflegten mittelalterlichen Erzählkunst der germanischen Länder," Frühmittelalterliche Studien, 5 (1971), esp. pp. 162-67. 
son from Grettis saga may be literary in their received form, they may be assumed to reflect the original mnemonic unit of popular tradition.

Less neatly defined as structural entities are episodes and pættir, but they nonetheless stand out as formulaic elements of plot by virtue of their recurrence and predictability. Episodes are brief subplots: scenic sequences recounting thefts, seductions, litigations, weddings, horse fights, and the like. Pættir are recurrent stories of a detachable, hence semi-independent, nature, also describing typical action patterns (e.g., the Travel Pattern and the Feud Pattern). Pættir in particular show signs of a literary hand, but they, too, like scenes and episodes, have an anecdotal quality that leads one to associate them with popular tale telling at an earlier stage. It falls outside the scope of this study to reconstruct the oral saga, but one can speculate that its narrative composition was more like that of the pættir or the fornaldarsogur than the Icelandic saga proper. ${ }^{48}$

There is little "oral" about the way these narrative parts are combined in complex wholes, however. ${ }^{49}$ Current opinion holds that interlace or stranded narration, particularly in simultaneous forms, is prima facie evidence of self-conscious literary authorship. Even without this corollary evidence, however, the Icelandic case would seem to be straightforward enough. The preclassical texts themselves dispel any notion that the form of composition in the classical sagas can be a venerable feature of popular tradition. What is striking about the early writings, particularly in

\footnotetext{
${ }^{48}$ Peter Buchholz contends that the fornaldarsaga is the most archaic and hence best surviving representative of oral saga tradition in Scandinavia. See his Vorzeitkunde: Mündliches Erzählen und Überliefern im mittelalterlichen Skandinavien nach dem Zeugnis von Fornaldarsaga und eddischer Dichtung, Skandinavistische Studien, 13 (Neumünster: Wachholtz, 1980).

49" The sagawriters did not have to import foreign rules for the construction of smaller units such as a battle scene, a goading scene, or even an entire feud episode. They did not have to learn abroad how to make the audience feel antipathy for the treacherous Loki figure or sympathy for a Siegfried figure fighting his last battle. They could use the old motifs and narrative rules which they had inherited from their ancestors; this was a heritage strong enough to resist many foreign influences even when the sagawriters were familiar with foreign literature. Their native literary grammar was too ingrown to be radically changed, but it could be modified and refined to suit new and more sophisticated literary interests, fostered by clerical minds of the thirteenth century"' (Lönnroth, Njals Saga, p. 103).
} 
contrast with those of the classical period, is the degree of variation in composition from text to text (e.g., Fagrskinna versus Morkinskinna) and even within the same text (e.g., Sverris saga). This would hardly be the case if saga composition were in fact taken over from an oral prototype. Moreover, there is discernible in the preclassical texts a sketchy but clear development from shorter works in which stranding is an occasional and rudimentary feature to longer works in which it is a regular and elaborate one-again, not the pattern we would expect if there were an oral prototype. In other words, as far as composition is concerned, recourse to an oral unknown is unnecessary. The extant literary documents themselves provide an adequate and plausible model of the evolution of the complex saga. Oral tradition may have been instrumental in the preservation and framing of the particulars, but there is no reason to suppose that their organization in large, convoluted wholes is anything other than a literary development of the twelfth century-a development in which the Latin connection played a decisive role. ${ }^{50}$

Sigurour Nordal argued that Norse prose began as factual knowledge but yielded by degrees to art for purposes of entertainment, with the classical sagas representing the optimal combination. The saga "begins as fact, ends as fiction, and progresses through every shade in between," he wrote; and further, "All true saga-writing is a balance between fact and art." 51 A survey of composition during the preclassical period suggests that "art" in this case is not a thing apart from the factual sphere of chronicle and history, but itself derived directly from that sphere, and further that this development is by no means peculiar to Iceland, but is part of the larger European development. This association is important to remember in connection with sagas such as Heiðarviga saga, Reykdola saga, and even the Legendary

\footnotetext{
${ }^{50}$ Especially suggestive for the Norse case is Peter M. Schon's study of the transition, in French tradition, from chronicle prose to literary prose, "Studien zum Stil der frühen französischen Prosa," Analecta Romanica, 8 (1960), 1-60.

${ }^{51}$ Nordal, Snorri Sturluson, esp. p. 131; reiterated in somewhat modified form in his "Sagalitteraturen," esp. pp. 27-73. Cf. Bjami Guơnason, Um Skjöldungasögu (Reykjavík: Bókaútgafa Menningarsjoðs, 1963), esp. pp. 269-83. See also Walter Baetke, Uber die Entstehung der Isländersagas, Berichte uber der Verhandlungen der Sächsischen Akademie der Wissenschaften zu Leipzig, phil.-hist. Kl., 102, pt. 5 (1956), pp. 5-108, esp. pp. 51-54.
} 
Saga - works thought by virtue of their early date to be relatively uncontaminated specimens of native narrative traditions. The year 1226 may be a watershed date in some respects, but on the level of composition Norse prose had contracted its foreign debt well before that. Latin chronicle writing played a role in the development of art prose in Scandinavia no less than on the Continent, and even the earliest sagas are too late not to have felt its influence.

\section{Romance and Saga}

If the preceding model is correct, the composition of the classical sagas is explained as the result of a largely domestic development, one shaped in the early stages by Latin practice but evolving on its own terms after that. The question is whether this model is sufficient to explain the numerous and striking correspondences, outlined in the earlier chapters of this book, between classical saga narrative and Continental narrative, above all, the mass of cyclic literature that came to dominate the French literary picture at the same time that the saga was rising to preeminence in Iceland. In both the saga and the prose romance we are dealing with full-length imaginative works in prose. In both cases, open composition is the point of departure for their genesis and the basic principle of their construction. And in both cases, interlace is used, not merely in "practical" forms, but in gratuitously developed and extended forms. The specific patterns differ: prose romances pursue fewer lines at greater length and focus on remarkable chronological coincidences, whereas the sagas intertwine a larger number of shorter strands in the interest of tracing webs of acts and consequences in the broader social fabric. In the sagas, that is, the intervals are typically shorter but the data more numerous and the fragmentation of the plot far more extreme. But in their copiousness, their interweaving of synchronic plot lines, and their obvious delight in the aesthetic of multiplicity and recurrence, the sagas and the prose romances are so alike that it is hard to suppose that they are unrelated.

Equally intriguing are the parallels in development. Like early saga tradition, early romance tradition seems to derive in part from Latin practice the techniques and language of digression 
(both external and internal). Both traditions assimilate the Latin figure gradually. In the first phase (the preclassical Norse texts and the poetic romances), digression or interlace is occasional and straightforward in form. In the second phase (the classical sagas and the prose romances), it has become a regular and artful feature of the narrative. In the third phase (e.g., Flateyjarbók and the Prophécies de Merlin) it is no longer a question of composition but of gross compilation. Particularly telling is the corresponding evolution of transitional phrases: from the infrequent use of a variety of phrases directly translating the Latin aphodoi to the abundant use of a few standard formulas in the later period. In both cases the gradual depersonalization of these phrases gives them a colloquial flavor in the later stages that tends to obscure their bookish origins. The romance model is most immediately helpful in understanding the rapid evolution of the saga from shorter and clearer plots to the voluminous amalgams of the later period.

These correspondences may be said to constitute the circumstantial evidence for the influence on saga writing of cyclic tradition. The immense popularity of the prose romances relative to many of their verse predecessors should not be forgotten. As Vinaver points out, the Prose Tristan "easily superseded all the poetical versions of the legend," becoming from the thirteenth century onward "the only recognized form of the Tristan story.... Throughout Europe the Prose Tristan was read and imitated, and its rifacimenti in the various European languages often became classics in the countries in which they appeared" (e.g., Malory's Morte Darthur [Books 8-12] in England and La tavola ritonda in Italy). ${ }^{52}$ The poetic versions dropped out of circulation until their reintroduction in 1823 and 1835 with the publication of Beroul's and Thomas's fragments respectively. ${ }^{53}$ The equivalent popularity of the Prose Lancelot is attested by the survival of about a hundred manuscripts and its impact on other romances all over Europe. ${ }^{54}$ Given the prominence of the prose

\footnotetext{
52Eugène Vinaver, "The Prose Tristan," in Arthurian Literature in the Middle Ages, ed. R. S. Loomis (Oxford: Clarendon, 1959), p. 346.

s3Ibid., p. 346.

${ }^{54}$ Jean Frappier, "The Vulgate Cycle," in Loomis, Arthurian Literature, pp. 317-18. See also chapter 1 , note 2 , above.
} 
phenomenon and the fact that it was the growth sector of medieval literature, it is hard to suppose that any Icelander at that time who knew anything at all about French literary culture could have been ignorant of it. Moreover, because the novelty of the prose romances lay less in the stories they told (most of which were known already in some form or other) than in the way they were knitted together in large, interlocking wholes, it may reasonably be supposed that "influence" in this instance would take the form of technical imitation, not necessarily plot borrowing. ${ }^{55}$ It may indeed be argued that, given the vigor of their own literary culture and the multifarious nature of their own quasi-historical traditions, the Icelanders were particularly susceptible to this literary fashion.

Material evidence for the influence of prose romance on saga writing is harder to come by. ${ }^{56}$ The only sure point of contact between saga and romance is the translation into Norse of such verse works as Yvain, Erec et Enide, Perceval, Tristan, and the lais of Marie de France. Commissioned in the first instance by Hákon Hákonarson, these translations appear to have found a ready audience in Scandinavia, and words and motifs from them quickly passed into general circulation, as their incorporation in sagas on native subjects attests. For the most part, recent inquiry into Franco-Norse literary relations has been limited to this and other equally demonstrable connections (e.g., Karlamagnús saga). The possibility of influence from untranslated works, or works not otherwise known to have been translated, remains a

${ }^{55}$ It is this sort of formal influence, rather than a material influence, that Heusler thought the Irish sagas might have exerted on Norse storytelling traditions. See his "Die Anfänge der isländischen Saga" in Andreas Heusler: Kleine Schriften, ed. Stefan Sonderegger (Berlin: de Gruyter, 1969), pp. 427-29; originally published in Abhandlungen der Königlich Preussischen Akademie der Wissenschaften, phil.-hist. Kl. (1913). See also Baetke, Uber die Entstehung der Isländersagas, pp. 82-98, and Guơnason, Um Skjöldungasögu, pp. 243-83. Jean Rychner's systematic analysis of "articulation" techniques in the Mort Artu suggests a basis for the further comparison of prose romance narrative with the sagas. See his L'articulation des phrases narratives dans la Mort Artu, Université de Neuchâtel: Recueil de Travaux de la Faculté des lettres, 32 (Geneva: Droz, 1970).

${ }^{56}$ The question of just how conversant the Icelanders were with French culture was debated recently by Theodore M. Andersson, "Skalds and Troubadours," Mediaeval Scandinavia, 2 (1969), esp. pp. 13-16, and Bjarni Einarsson, "The Lovesick Skald: A Reply to Theodore M. Andersson," Mediaeval Scandinavia, 4 (1971), esp. 28-36. 
largely unexplored field. There is only one claim based on the criterion of plot correspondence that a prose romance was known in Iceland, and it has been challenged. ${ }^{57}$ Even if it is genuine, it alone is too late to have affected the early development of the saga.

Because of the problems in dating the family sagas, it is hard to draw any firm conclusions about the evolution of the form during the course of the thirteenth century. In general, it would seem that the cyclic tendency is more conspicuous in the later, longer sagas of the district chronicle type than in the earlier, shorter sagas of the biographical type, but it is in any case sufficiently evident even in those sagas we regard as oldest (including Heiðarvíga saga and Reykdola saga, a district chronicle recently redated to $1207-20)^{58}$ that if we are to assume influence from cyclic romance, we must suppose that it began in the first or second decade of the century. This is not, strictly speaking, impossible. Like the saga, the prose romance had its preclassical phase in the years before and after 1200 in the works of Robert de Boron (whose tetralogy is dated between 1190 and 1212, probably around 1202) and the highly stranded Perlesvaus (the original version of which appeared between 1191 and 1212). The "classical" cyclic works, like the classical sagas, belong to the thirteenth century proper: the Vulgate Cycle is generally dated between 1215 and 1230 and the first version of the Prose Tristan between 1225 and 1235 (the second version comes from the latter half of the century). The early vigor of the cyclic idea is suggested by the translation into German of the Prose Lancelot not long after the date of its original composition. The rise of cyclic romance, in other words, is exactly contemporaneous with the rise of the saga. To claim, therefore, that the former played a critical role in the development of the latter requires us to assume (1) that the connection was unusually efficient and did not entail the usual

\footnotetext{
${ }^{57}$ In his Skaldasögur: Um uppruna og eoli ástaskaldasagnanna fornu (Reykjavík: Bókaútgafa Menningarsjoðs, 1961), Bjarni Einarsson argued that the Prose Tristan is reflected especially in Kormaks saga (pp. 75-76). Cf. Andersson ("Skalds and Troubadours," pp. 38-41) and Einarsson's reply ("The Lovesick Skald," pp. 38-41).

58Dietrich Hofmann, "Reykdœla saga und mündliche Überlieferung," Skandinavistik, 2 (1972), 1-26. The highly digressive structure of Sturlunga saga should be noted in this connection.
} 
time lag (compare the lapse of eighty-odd years between the time of Chrétien's original publication and the time of the Norse adaptation); (2) that the cyclic idea was adopted immediately and more or less unanimously by Norse authors; and (3) that the cyclic idea reached Scandinavia before the translation of the verse romances. None of these assumptions is in itself implausible, but taken together they depart too emphatically from some of our basic presuppositions about Norse literary history to be wholly convincing.

In light of this problematic chronology and in the absence of hard evidence, it is difficult to suppose that the prose romances played a decisive role in the formal development of the saga. The more prudent assumption is that the saga and the prose romance represent, at least in the early stages, independent responses to a common medieval aesthetic (chronicle writing, first Latin and then vernacular, being an important factor in both cases). This is not to say that the cyclic idea never penetrated Scandinavia-it is clear from Flateyjarbók that it did-but that it may have come later rather than earlier and that its effect was not so much formative as it was to reinforce preexisting narrative tendencies and perhaps to contribute certain technical refinements (e.g., the use of suspended animation at transition points). Such a secondary influence may explain at least some of the striking surface similarities between the two traditions. In either case, whether saga composition is to be explained as the result of independent development out of Latin practice, or as a direct imitation of prose romance, or as a combination of the two, the larger point is clear: it belongs to the general European development of the late twelfth and thirteenth centuries.

\section{The Two Audiences}

The idea that the sagas were orally delivered to a listening public-the sagnaskemmtun or "saga entertainment"-enjoys a current consensus in saga studies. The evidence, conveniently collected in Hermann Pálsson's Sagnaskemmtun Íslendinga (1962), ${ }^{59}$ suggests that sagnaskemmtun in the preliterate period

${ }^{59}$ Hermann Pálsson, Sagnaskemmtun İslendinga (Reykjavík: Mál og Menning, 1962). 
involved telling a traditional story more or less from memory, but that this practice gave way at some early point to the reading aloud of sagas from manuscripts. Just when that change took place may be disputed, as may be the question of just what form the early "told" sagas took. Generally accepted, however, is the idea that the canonical sagas were read aloud, in something like the form we have them, probably in nightly installments (Njáls saga would require about two weeks), in conditions not unlike those of the famous Reykjaholar wedding in 1119: at a larger farm, in connection with a special occasion, and to socially mixed company (prominent landowners, clerics, merchants, independent farmers, women). ${ }^{60}$

60“'Par var nú glaumr ok gleði mikil, skemmtan gő ok margs konar leikar, bæర̋ dansleikar, glímur og sagnaskemmtan. par var sjau nætr fastar ok fullar setit at boðinu, af pví at par skyldi vera hvert sumar Oláfs-gildi, ef korn gæti at kaupa, tvau mjölsáld, á bórsnesspingi, ok váru par margir gildabræơr.... Frá pví er nökkut sagt, er pó er lítil tilkváma, hverir par skemmtu eð̃a hverju skemmt var. Pat er í frásögn haft, er nú mæla margir í móti ok látast eigi vitat hafa, bví at margir ganga dulðir ins sanna ok hyggja pat satt, er skrökvat er, en pat logit, sem satt er: Hrólfr frá Skálmarnesi sagôi sögu frá Hröngviơi víkingi ok frá Oláfi Liősmannakonungi ok haugbroti práins berserks ok Hrómundi Gripssyni—ok margar vísur með. En pessari sögu var skemmt Sverri konungi, ok kallað̋i hann slíkar lygisögur skemmtiligstar. Ok pó kunna menn at telja ættir sínar til Hrómundar Gripssonar. Pessa sögu hafơi Hrólfr sjálfr saman setta. Ingimundr prestr sagoi sögu Orms Barreyjarskálds ok vísur margar ok flokk gớan viō enda sögunnar, er Ingimundr hafoi ortan, ok hafa pó margir frő́ir menn pessa sögu fyrir satt." ("Now there were high spirits and great merriment, good entertainment and many kinds of amusements: dancing, wrestling, and storytelling. They [the guests] sat at the feast for a fixed period of seven full nights, because there was supposed to be a Feast of St. Olafr at the Porsnes Thing every summer during which they could purchase two meal-measures of grain, and there were many guild-brothers present. Something is told, though it is of little consequence, about those who entertained there and what the subject of the entertainment was [i.e., who told stories and what these stories were]. Stories are told, which many people now disclaim or act as if they never knew, because many are blind to the truth and regard those things as true which are fabrications and those things as lies which are true: Hrolfr from Skálmarnes told a saga about Hröngviơr the viking and about Oláfr Liơsmannakonungr and the grave robbery of prainn the berserk and Hrómundr Gripsson-along with many stanzas of poetry. This saga was told to King Sverrir, and he declared such lying-sagas to be most amusing. Yet people can trace their families back to Hrómundr Gripsson. Hrolfr himself had composed [lit. "put together"] this saga. Priest Ingimundr told the saga of Ormr Barreyjarskáld, with many stanzas of poetry and, at the end of the saga, a good flokkr which Ingimundr had made, and even so, many wise men consider this saga to be true"-Porgils saga ok Haflioa, chap. 10.) On the authenticity of the passage, see Peter G. Foote, "Sagnaskemtan: Reykjahollar 1119," Saga-Book of the Viking Society, 14 (195556), 226-39. 
The picture of the sagnaskemmtun is in agreement with the picture, generally accepted until recently, of the Middle Ages as an era when vernacular literature was orally disseminated in some way or other, even among the literate laity. ${ }^{61}$ As Ruth Crosby put it, medieval people "read by means of the ear rather than the eye, by hearing others read or recite rather than by reading to themselves." 62 In the earlier period, oral performances took the form of the recitation or chanting of tales by professional performers (jongleurs, scops, skalds) in the halls of the nobility as well as for common people on the streets. As illiteracy gave way to oligoliteracy, oral performance, at least among the privileged classes, increasingly took the form of the reading aloud from a manuscript by someone (first a professional, later a member of the family). Two kinds of evidence are advanced for the custom of reading aloud. One is extrinsic and consists of passages actually describing the act and circumstances of such readings (e.g., Chrétien's description, in Yvain, of a pucele who reads aloud to her family from a manuscript in Old French). ${ }^{63}$ The other kind of evidence is intrinsic and consists of phrases apostrophizing the listener, often in prologues or conclusions: "Or escoutez, granz et menour (Now listen, lords and lowborn)" or "Herkneth to me, gode men, / Wiues, maydnes, and alle men." 64 The superfluity of listenerphrases in the verse romances led an earlier generation of

${ }^{61}$ See in particular H. J. Chaytor, From Script to Print: An Introduction to Medieval Literature (Cambridge: Cambridge University Press, 1945); Ruth Crosby, "Oral Delivery in the Middle Ages," Speculum, 11 (1933), 88-110; Albert C. Baugh, "The Middle English Romance," Speculum, 42 (1967), 1-31; and Pierre Gallais, "Recherches sur la mentalité des romanciers français du moyen age: Les formules et le vocabulaire des prologues," Cahiers de civilisation médiévale, 7 (1964), 479-93.

${ }^{62}$ Crosby, "Oral Delivery," p. 88.

${ }^{63}$ [Yvain] apoiié voit dessor son cote / Un prodome qui se gisoit / Sor un drap de soie, et lisoit / Une pucele devant lui / An un romanz, ne sai de cui. / Et por le romanz escouter / S'i estoit venue acoter / Une dame, et c'estoit sa mere, / Et li prodon estoit ses pere, / Si se pooient esjoïr/Mout de li veoir et oir. ([Yvain] sees, reclining upon his elbow upon a silken rug, a gentleman, before whom a maiden was reading from a romance about I know not whom. There had come to recline there with them and listen to the romance a lady, who was the mother of the damsel, as the gentleman was her father; they had good reason to enjoy seeing and hearing her, for they had no other children"-vv. 5362-72).

${ }^{64}$ Further examples in Crosby, "Oral Delivery," and Chaytor, From Script to Print, Appendix B (pp. 144-47). 
scholars to assume that they were the compositions of unlettered minstrels. But now that the bookish nature of the works has been firmly established, their "oral" phrases are taken rather as reflections of their intended mode of delivery. Because authors realized that their works were probably not destined for dissemination solely through the multiplication of manuscripts, they wrote, according to Albert C. Baugh, "with oral presentation in mind, adopting a style, so far as they were capable of it, natural to live presentation." 65 Circumstances required that the literary work imitate the oral form.

The question has recently been raised whether the case for oral reading has not been overstated and whether rather more medieval literature was intended for private reading than has been supposed.$^{66}$ Estimates of the degree of literacy among the laity are not much help because they vary greatly and do not distinguish the partially literate (able only to read) from the fully literate (able to read and write), not to speak of degrees of ability within those categories. ${ }^{67}$ That some people could and did read vernacular poetry would seem to be indicated by the occurrence of references, admittedly fewer, to readers as well as listeners. ${ }^{68}$ The

${ }^{65}$ Baugh, "Middle English Romance," p. 9. See also Ramón Menéndez-Pidal, Poesía juglaresca y juglares (Madrid: Espasa-Calpe, 1924), pp. 274-79; and Gallais, "Recherches," pp. 479-93.

${ }^{66}$ See especially Martín de Riquer, "Épopée jongleresque à écouter et épopée romanesque à lire," Actes du Colloque de Liège (Sept. 1957): La technique littéraire des chansons de geste (Paris: Société d'édition "Les Belles Lettres," 1959), pp. 75-84; G. B. Gybbon-Monypenny, "The Spanish Mester de Clerecia and Its Intended Public: Concerning the Validity as Evidence of Passages of Direct Address to the Audience," Medieval Miscellany Presented to Eugène Vinaver, ed. Frederick Whitehead et al. (Manchester: Manchester University Press, 1965), pp. 230-44; Roger Walker, "Oral Delivery or Private Reading? A Contribution to the Debate on the Dissemination of Medieval Literature," Forum for Modern Language Studies, 7 (1971-72), 36-42; and Ian Michael, "A Comparison of the Use of Epic Epithets in the Poema de Mio Cid and the Libro de Alexandre," Bulletin of Hispanic Studies, 38 (1961), 32-41.

${ }^{67}$ Two useful books on medieval literacy are James Westfall Thompson, The Literacy of the Laity in the Middle Ages, University of California Publications in Education, 9 (Berkeley: University of California Press, 1939; rpt. New York: B. Franklin, 1963), and M. T. Clanchy, From Memory to Written Record: England, 1066-1307 (London: Edward Amold, 1970; rpt. 1979). Further bibliography can be found in these works and in Franz H. Bäuml, "Varieties and Consequences of Medieval Literacy and Illiteracy," Speculum, 55 (1980), 237-65.

${ }^{68}$ Examples are given by Crosby, "Oral Delivery," pp. 99-100. 
question is, of course, how authentic such phrases are as indicators of audience. The "oral" formulas in particular may have been part of the conventional baggage of vernacular poetry, understood by author and audience alike to be quaint remnants of the minstrel era. This would seem to be the lesson of those examples occurring in works known to have been written for private readers. ${ }^{69}$ Peter M. Schon came to this conclusion about the listener formulas in early French prose: they remained part of the author's stock in trade long after the oral situation ceased to obtain. ${ }^{70}$ But in either case, the likelihood that verse romances were customarily read aloud does not detract from the likelihood that they were also read privately and that their authors were aware that both forms of publication were possibilities.

What, then, of prose? It is a commonplace that the rise of prose for purposes of entertainment and edification is associated with the spread of education. Aware of the possibility that their works might be read privately as well as publicly, authors abandoned the traditional vehicle of oral performance (indeed, of fiction or legend in general), the verse form. Some literary historians assume a period of transition. ${ }^{71}$ Others, like Schon, incline to the view that the use of prose was by definition indicative of a significant number of private readers. ${ }^{72}$ That the prose romances were aimed at readers, not listeners, is suggested by the paucity of the conventional signs of oral delivery (passages describing it and exhortations to listeners) ${ }^{73}$ as well as another kind of intrinsic

${ }^{69}$ See Gybbon-Monypenny, "The Spanish Mester de Clerecia"; Michael, "Comparison of the Use of Epic Epithets," pp. 32-41; and Walker, "Oral Delivery or Private Reading?" pp. 37-38.

${ }^{70}$ Schon, "Studien zum Stil der frühen französischen Prosa," pp. 141-43 and 159-63. Gybbon-Monypenny ("The Spanish Mester de Clerecia") points out that words such as "say" and "hear" are often used catechrestically "in the way that a modern writer will "say" things to his readers" (pp. 242-43).

${ }^{71}$ E.g., Chaytor, From Script to Print, pp. 141-43.

${ }^{72}$ Schon, "Studien zum Stil der frühen französischen Prosa," pp. 141-43; also Georges Doutrepont, Les mises en prose des épopées et des romans chevaleresques du XIVe au XVI é siècle, Mémoires de l'Académie royale de Belgique, classe des lettres, 40 (Brussels, 1939), esp. pp. 380-441.

${ }^{73}$ Of the derhyming process, Doutrepont writes: "As a general rule, the epic mechanisms and phrases disappear-that is, the call for attention or for silence; the repetitions or the summaries, indispensable in the recitation of chansons de geste; the epithets serving as leitmotifs. All of these economies may be explained: the use of the mechanisms and phrases, technical concomitants of the epic genre, 
evidence: their complex narrative structure. It has often been noted that narrative intended for oral delivery, even when it is written by fully literate authors, tends to have the characteristics of oral narrative. As Franz Boas once put it, "The form of modern prose is largely determined by the fact that it is read, not spoken, while primitive prose is based on the art of oral delivery and is, therefore, more closely related to modern oratory than to the printed literary style." 74 Narrative form, in other words, reveals as much about those who consume it as those who produce it; an author can finally be no more "literate" or "literary" than his or her audience. At least one critic has for this reason classified as "oral" all poetry intended for oral delivery regardless of the circumstances of its origin (a view, however, that has not met with general approval). ${ }^{75}$

This correspondence in form between orally composed narrative and texts written by literate authors for reading aloud may in part be the result of a deliberate effort to imitate popular practice; but it may also be an unconscious acknowledgment of something intrinsic in the act of listening, a set of limitations the situation imposes on literate and illiterate alike. The underlying idea is that the listener cannot tolerate the same degree of formal complexity as the reader, who, as $\mathrm{H}$. J. Chaytor puts it, "has time to ponder the matter before him, to read a passage over as often as he pleases and to exert his critical faculties." 76 On these grounds, more than any other, the prose romance distinguishes itself from its verse predecessors. The verse romances as a group may have story lines suitable for oral delivery, but the reverse is true of the prose romance, of which it may be said (as Roger Walker said of

has no reason to exist once the genre itself ceases to exist. Indeed, it would have been absolutely impossible to maintain them. Another factor motivating the disappearance of the 'apparatus' of epic is that, being set in prose, they [the dehymed works] were not addressed to the ear but to the eye. The reader reads; he does not hear" (Les mises en prose, p. 565); and further: "All this more or less artificial framework [i.e., the 'oral' features] arose almost by necessity from the force of circumstances. But starting as early as the thirteenth century, it begins to disappear" (ibid., p. 685).

${ }^{74}$ Franz Boas, "Stylistic Aspects of Primitive Literature," Journal of American Folk-Lore, 38 (1925), 329-39.

${ }^{75}$ Ruth Finnegan, Oral Poetry (Cambridge: Cambridge University Press, 1977), esp. pp. 16-24.

${ }^{76}$ Chaytor, From Script to Print, p. 80. 
the Zifar, a Spanish example from ca. 1301) that "its huge length, slow-moving plot, complex structure, high level of abstraction and constant moralizing conflict at every turn with the vivacity, actuality and concreteness that are the salient features of all mass oral literature, whether orally composed or merely orally diffused." "77 It should be remembered that there is a certain medieval authority for the idea that narrative intended for private reading may indulge more complex forms of exposition than narrative intended for oral delivery-explicitly in the form of rhetoricians' rules ("Circuitous development ... dulls the mind of the listener by making an unsolvable labyrinth, unless the listener is very subtle"') and implicitly in practice (e.g., Alcuin's differently ordered versions of the same saint's life for different audiences). ${ }^{78}$

The extrinsic evidence for the oral delivery of sagas has been collected elsewhere and will be discussed only briefly here. ${ }^{79}$ It consists of a handful of medieval references to specific occasions and the more numerous accounts, from later centuries, of the practice of oral reading on Icelandic farms. The latter assume the status of evidence by virtue of the common supposition of an extraordinary degree of cultural continuity in Iceland during and after the Middle Ages. ${ }^{80}$ The medieval descriptions proper are few and notoriously inconclusive. It is not always clear, for example, whether they refer to recitation (as is assumed to be the case in the Reykjaholar passage) or reading aloud (as the wording of the "Huldar saga" passage in Sturlunga saga would seem to suggest). ${ }^{81}$ Nor are the references informative on the question of

${ }^{77}$ Walker, "Oral Delivery or Private Reading?" p. 40.

${ }^{78}$ See Chapter 3, esp. notes 23-27.

${ }^{79}$ See Pálsson, Sagnaskemmtun Íslendinga.

${ }^{80}$ In a similar way, Stefán Karlsson argues that an unusually high degree of literacy in sixteenth-century Iceland must reflect a high degree of literacy there in the Middle Ages-a view rejected by Lönnroth. See Stefán Karlsson, "Ritun Reykjarfjarðarbókar. Excursus: Bókagerơ bænda," Opuscula, 4, Bibliotheca Arnamagnæana, 30 (Copenhagen: Munksgaard, 1970), pp. 120-40; Lönnroth, Njals Saga, pp. 166-70. If we regard as evidence of its medieval currency the practice of sagnaskemmtun in later centuries, so we must by the same token acknowledge the unusually high incidence of Icelandic literacy in later centuries as an indication of a relatively large number of readers in medieval Iceland.

${ }^{81}$ Related in "Sturlu páttr"' (Sturlunga saga, II, 232-35). Sturla Póróarson entertains King Magnús with the oral delivery of "Huldar saga." Pálsson (Sagnaskemmtun Islendinga, p. 52) and Lönnroth (Njals Saga, p. 173) assume, on grounds of the wording, that a manuscript is involved: Magnús, in requesting the 
form. A rare mention of length is found in the Morkinskinna description of the recitation of Haraldr harơrái's útferðar saga; the king and the Icelander conspire to stretch the saga over the thirteen evenings of Yule by dividing it into unusually short segments. ${ }^{82} \mathrm{~A}$ further complication lies in the uncertainty of the exact meaning of the word "saga." The possibility should be considered that the memory of the "saga," like other orally transmitted memories, was unconsciously adjusted by each generation to its own experience and that the thirteenth-century commentators were themselves in some degree unwitting heirs to and purveyors of an anachronism. ${ }^{83}$ The mere persistence of the word "saga" is no guarantee that the thing itself did not undergo changes during the two centuries in question (modern readers may be in a better position than the medieval Icelanders to speculate on the nature of that change). Finally, of course, there is the often-noted fact that, as B. M. Olsen put it, there is to be found in the early literature "no evidence that such saga-tellers chose family sagas as their subject matter." 84 The records mention numerous tales of a fantastic sort, as well as stories of kings and saints, but no Icelandic matter. However reasonable it may be to assume that this omission is an accident of history and that "sagas" on

performance, asks Sturla to "bring with him the saga about the troll-woman (hafa meó sér trollkonusöguna)." Hofmann disagrees: "It is most unlikely that Sturla would have read the saga aloud [to Magnús]. In his reduced circumstances-'hafoi hann nær ekki i fé [he had almost no property],' it says in connection with his departure from Iceland, and for his voyage he didn't even have his own provisions along - he would scarcely have carried a manuscript around with him, especially one of entertainment value only. Nor could it have comprised only a few leaves, because he recited the saga for the better part of the day, as the second mention indicates ('sagoi mikinn hluta dags sögu')" ("Vers und Prosa," p. 168). A clear case of reading is found in Porgils saga skarda (in Sturlunga saga, II, 218), in which Porgils asks to have Tómas saga erkibyskups read to him.

${ }^{82}$ Morkinskinna, pp. 199-200. A recent discussion of this passage as it relates to other oral traditions is that of H. M. Heinrichs, "Mundlichkeit und Schriftlichkeit: Ein Problem der Sagaforschung," Akten des V. Internationalen GermanistenKongresses, Cambridge 1975, published as Ser. A, vol. 2 of Jahrbuch für Internationale Germanistik (Bern: Herbert Lang, 1976), 114-33.

${ }^{83}$ For an illuminating discussion of memory in oral tradition, see Jack Goody and Ian Watt, "The Consequences of Literacy," in Literacy in Traditional Societies, ed. Jack Goody (Cambridge: Cambridge University Press, 1968), pp. $27-68$.

${ }^{84}$ Björn M. Ólsen, “Um Íslendingasögur,’ Safn til sögu Íslands, 6 (1937-39), p. 9. 
local subjects must have been disseminated in more or less the same way as "sagas" on other subjects, the fact remains that there is no record to that effect. As bookprosists have often pointed out, we have no real extrinsic evidence from the medieval period that Icelandic sagas were orally delivered in any form.

Also in short supply in the Icelandic sagas are the usual intrinsic signs of oral delivery, such as passages addressing the listener. As indirect evidence that they were read aloud have been cited the handful of audience exhortations found in the riddarasogur ("Hafi sá pökk, er las, og sá, er skrifað̃i, ok allir peir, er til hlyðða [Let him be thanked who read, him who wrote, and all those who listened]'), but these tell us more about the redactors' eagerness to imitate a foreign convention than they do about how romances actually circulated in the Norwegian court, not to say how native sagas circulated in Iceland. ${ }^{85}$ The absence of equivalent exhortations in the Icelandic sagas may be explained as part of their narrative stance, which excludes apostrophe, but the question must then be asked whether this narrative stance is compatible with the usual requirements of oral delivery. The only "oral" phrases in the Icelandic sagas are such formulas as nú er at segja, er frá var sagt-phrases that may or may not be remnants of an oral stage of storytelling but in either case cannot be taken as an indication of oral delivery in and of themselves (particularly given their apparent interchangeability with "writer" phrases). ${ }^{86}$

${ }^{85}$ The example is from the end of Rémundar saga keisarasonar. Elis saga ok Rósamundu contains the following admonition: "Nú hlyð̋io góogæfliga! Betra er fögur fræơi en kviðar fylli; pó skal viơ sögu súpa, en ei of mikið drekka. Sæmd er sögu að segja, ef heyrendur til hlyða, en tapað starfi að hafna að heyra (Now listen well! A fair tale is better than a full belly. One should sip while listening to a saga, but not drink too much. It is an honor to tell a story when the audience pays attention, but a vain effort when they stop listening)." As Damsgaard Olsen points out ("Den høviske litteratur" in Norron fortællekunst, p. 108), this is an expansion of the French or m' escoutes signor. See also Lönnroth, Njals Saga, pp. 172-73.

${ }^{86}$ The significance of such phrases in the sagas has been disputed. Liest $\varnothing 1$ took them at face value as oral remnants; Baetke dismissed them as "validating" clichés, not to be taken seriously; Andersson, reviewing the evidence more systematically, concluded that a certain portion of them must constitute textual evidence of a prehistoric oral saga. To the debate may be added a modern note-the function of such phrases in establishing what Ong calls the "audience fiction." Just as the use of folktale language by H. C. Andersen and Karen Blixen is not an indication that they intended their stories to be read aloud but rather that they 
But it is above all the formal structure of the saga that speaks against its having been intended solely or even mainly for oral publication. The problem is not length per se, which is attested as an "oral" possibility in living epic traditions ${ }^{87}$ nor is it prose per se, which is after all the vehicle of the folktale (though the combination of nonrhythmic prose and length is uncommon in the world of oral entertainment $\left.{ }^{88}\right)$. Nor is it style; the language of the sagas is a model of clarity, and even if it does not reflect an oral style as much as a literary idealization of an oral style-"more natural than nature" (Nordal) or "unnaturally natural" (Heusler)—it is in any case not "literary" in the usual sense. Nor, as I have suggested earlier, does the difficulty lie in the smaller denominations of plot-scenes, episodes, pættir. These, too, have an anec-

expected their readers to imagine themselves, for the duration of the narrative, in the role of children or naive listeners, so may the "oral" language of the saga be little more than an invitation to a nostalgic fiction ("Listen, my children, and you shall hear / Of the midnight ride of Paul Revere ..."). See Knut Liest $\emptyset 1$, Upphavet til den islendske ættesaga (Oslo: Aschehoug, 1929), esp. p. 36; Walter Baetke, Über die Entstehung der Isländersagas, esp. pp. 29-31; Theodore M. Andersson, "The Textual Evidence for an Oral Family Saga," Arkiv för nordisk filologi, 81 (1966), 1-23; and Walter J. Ong S.J., "The Writer's Audience Is Always a Fiction," PMLA, 90 (1975), 9-21.

${ }^{87} \mathrm{~A}$ late fourteenth-century instance of a long oral reading is described by Froissart in his Dit du Florin. He tells how he read his poetic romance Méliador (more than 30,000 lines long) to Gaston Phébus. Even Chaytor doubts comprehensibility under the circumstances (From Script to Print, pp. 103-4).

${ }^{88} \mathrm{~T}$ wo recent attempts to see saga literature in the context of larger oral tradition are, with reference to the Icelandic sagas, Heinrichs, "Mündichkeit und Schriftlichkeit," and, with reference to the fornaldarsogur (legendary sagas), Buchholz, Vorzeitkunde. The difficulty in both cases is that the majority of cited evidence is from poetic traditions, for the reason that oral narrative is almost by definition poetic narrative. As Robert Scholes and Robert Kellogg summarize: "It is the universal experience of mankind that the oral composition of prose sentences is more difficult than the oral composition of metrically perfect verse. Some critics believe that prose cannot develop orally because of the difficulty of controlling the logical and syntactic rhythm of the prose sentence. They have restricted illiterate man to the esthetic use of verse" (The Nature of Narrative [New York: Oxford University Press, 1966], pp. 50-51). Such prose traditions as do exist appear to be markedly rhythmic and repetitive (see Finnegan, Oral Poetry, pp. 24-28 and 50-51, and Boas, "Stylistic Aspects of Primitive Literature"). An exception to the rule of verse, cited by both Heinrichs and Buchholz as possibly pertinent to the saga case, are prose traditions in central Asia (see esp. Buchholz, Vorzeitkunde, pp. 29-30); Buchholz also refers to Welsh, Scottish, and Irish traditions. Unfortunately for saga scholars, oral prose has not been given the same attention as oral verse, with the result that its "poetics" are poorly understood. 
dotal stamp and must represent an oral layer. The problem lies rather in the larger composition of the whole. The component parts may be perfectly lucid, but the way they are put together, not to say the sheer number of them, is not. At this level, even the freeprosists agree, the saga is a literary creation. Heusler's statement about Snorri's Óláfs saga helga is worth repeating, for it applies to the classical sagas in general: "[It] meshes complex and polycentric narrative masses into a whole that advances chronologically in such a way that a thread is interrupted and resumed several pages later. This sophisticated procedure lies far beyond the capacity of the preliterary saga tellers. In addition, the narrative parameters, the scope of the work, exceed the limit of oral performance." 89

But what of the audience? Heusler, like Olrik and others who have pronounced on the literary nature of saga composition, stopped short of the next logical step. The question is whether those features of the saga which are "far beyond the capacity of the preliterary saga tellers" were not also in some sense beyond the capacity of listeners-whether, that is, a literary form that presupposes a sophisticated author does not by the same token presuppose a sophisticated audience. In Vinaver's view, appreciation of interlace structure in prose romance was limited not only to a reader but only the cleverest reader: "So delicate an architecture presupposed in the reader and the writer an unusual discipline of mind and a span of attention which even in the thirteenth century could not have been the privilege of many."90 One saga critic who recognized that the convoluted structure of the saga was hard to reconcile with the concept of oral delivery was Hollander, but his implicit trust in the doctrine of sagnaskemmtun kept him from taking his own analysis to its logical conclusion. Rather than asking whether literary composition might not imply a literate audience, he posited a uniquely gifted group of listeners:

The modern reader, with a neatly printed text before him, can, to be sure, leaf back at his leisure to disentangle the skein of interbraided

${ }^{89}$ See chapter 2 , note 6 .

${ }^{90}$ Eugène Vinaver, The Rise of Romance (New York: Oxford University Press, 1971), pp. 92-93. 
events. But one marvels at the mental alertness of Icelandic listeners, ancient and modern, who could do this, and seeks refuge in the rather lame consideration that, after all, listening, like intelligent reading, is an art which can be acquired; also, that Icelanders heard these stories over and over again as our forebears heard the Biblical stories read to them, day in and day out. Even so, the sagas, and more especially this one [Eyrbyggja saga], cannot be read quasipassively, as can a unilateral story or a modern novel, but require a certain amount of co-operation on the part of the reader which, exempla docent, our scholars have not shown in this instance. ${ }^{91}$

As prefaces to popular editions of the sagas repeatedly point out, the Icelanders must have known a great deal about the particulars (genealogies, place names, anecdotes) that formed the historical matrix of the saga and contribute to the confusion of the modern reader. But familiarity with particulars is one thing and convoluted arrangement another-particularly when that arrangement strongly resembles the patterns of other contemporary European narrative of an unhistorical sort. (Nor, it should be added, were the plots and the imaginary world of Arthurian romance unfamiliar to the European reader of the thirteenth century.) The idea that saga listeners transcended the normal limits of the oral situation by dint of sheer repetition has two disadvantages: it posits Iceland as a society where the majority evidence ends and the minority evidence begins, and it presupposes a period and kind of evolution of which no historical record remains.

It is a tribute to the appeal of the sagnaskemmtun doctrine that, despite what is generally conceded to be an unusually high degree of literacy in medieval Iceland, ${ }^{92}$ the existence of a sophisticated

${ }^{91}$ Lee M. Hollander, "The Structure of Eyrbyggja saga," Journal of English and Germanic Philology, 58 (1959), 226-27.

${ }^{92}$ The classic contribution is that of Sigurour Nordal, "Tid och kalvskinn," Scripta Islandica, 5 (1954), 5-18; translated as "Time and Vellum," MHRA: Annual Bulletin of the Modern Humanities Research Association, 24 (1952), 15-26. See also Einar Olafur Sveinsson, "Lestrarkunnátta Íslendinga i fornöld," Skirnir, 118 (1944), 173-97; rpt. in his Við uppspretturnar (Reykjavík: Helgafell, 1956), pp. 166-92; and Karlsson, "Ritun Reykjarfjaroarbokar." A contrary view was argued by Lars Lönnroth, "Tesen om de två kulturerna: Kritiska studier $\mathrm{i}$ den isländska sagaskrivningens sociala förutsättningar," Scripta Islandica, 15 (1964), esp. pp. 52-77; and his Njals Saga, pp. 166-70. See note 80 above. 
readership of the sagas has never been cited as an explanation for their manifestly literary characteristics. There are two reasons for supposing that the thirteenth-century Icelandic reader might have grown impatient with the traditional forms of native storytelling and so indirectly contributed to their literary mutation. One is that by the mere fact of their literacy, readers were able to take in more numerous narrative data in more complex forms. The other is that, again by virtue of their literacy, readers had been exposed in varying degrees to foreign culture and thus had glimpsed a new range of literary possibilities. The Continental orientation of this elite readership is obvious both from the translating activity and from the incorporation into native sagas of learned and foreign matter. Narrative habit is harder to pin down, but the fact remains that the Icelanders developed the same taste for baroque exposition as their European neighbors-a literary development and a specifically medieval one, however the coincidence is to be explained.

Just how large this literate subgroup was can only be guessed at. It must have included clerics, wealthier people, and whatever other individuals had acquired the skill of reading and a taste for literature-including, of course, the saga authors themselves. There were, after all, at least as many readers in Iceland as there were writers, and that is already more than a few. Whatever other audience they had in mind, saga authors must also have been writing for each other. To concede the literary artistry of the saga is to concede a self-conscious artist, one who presumably studied the work of others with an eye to imitation or improvement. Just as, according to Egils saga, Einarr skálaglamm and Egill Skallagrimsson met at the Althing and conversed at length and pleasurably on the subject of poetry, "a topic they both found enjoyable,"93 so must saga authors have known one another and formed their own literary society. At some level, each individual

93،"Einarr gekk til bưoar Egils Skalla-Grímssonar, ok tókusk peir at oroum, ok kom par brátt talinu, at peir roeddu um skáldskap; pótti hvárumtveggja pær rơ̌ur skemmtiligar. Síóan vanöisk Einarr optliga at ganga til tals við Egil; gerơisk par vinátta mikil (Einarr went to Egill Skallagnimson's booth and they started talking. Their conversation quickly turned to poetry, a topic they both found highly enjoyable. After that Einarr made it a habit of often going to talk with Egill, and they formed a close friendship"-Egils saga, chap. 78). 
saga is a response to the sagas preceding it and a standard for those to come. One cannot but wonder whether the Atlantic Interlude of Njals saga is not to some extent artists' art, written primarily for the edification of other practitioners of the craft. However small the number of authors and readers in thirteenthcentury Iceland, they must by virtue of their literacy have formed a subgroup that for the individual author would have been a significant minority indeed. Like art prose in France, art prose in Iceland seems, as Georges Doutrepont said, to address itself "less and less to groups and more and more to individuals. It is created for particular people and not for the masses. One might even say that it [art prose] becomes, if we may agree on the meaning of the word, individualistic." 94 This is not to deny that the sagas were performed orally, but to suggest that even if the oral audience was the larger and more common one, it was not the only one-nor, by the thirteenth century, was it the primary or authoritative one so far as the composing artist was concerned. The obvious explanation for the often-noted fact that the Icelandic sagas combine oral tradition with literary innovation is to suppose that their authors intended them for both forms of publication. It is first and foremost to the anecdotes of the sagas-the wit and lapidary phrasing of which seem ideally suited for performance-that the listening audience must have responded in the saga read aloud, exactly as their forebears had in the saga told more or less from memory. The listening audience must also have followed the general drift of the plot (with which they were presumably familiar in some degree). But especially given the fact that the sagas were read in installments, the listening audience is unlikely to have appreciated the literary niceties of the larger plot-the precise relation of all the interlocking subplots, the long-range forecasts and correspondences, or the factor of time in simultaneous passages. These are the sagas' literary features, intended for the enjoyment of their private readers, for whom, as for the readers of the prose romances, the "exercise of memory was itself a pleasurable pursuit which carried with it its own reward." 95

It is probably simplistic to draw such a sharp distinction be-

${ }^{94}$ Doutrepont, Les mises en prose, p. 685.

${ }^{95}$ Vinaver, Rise of Romance, p. 83. 
tween the two audiences of the saga. In reality, there must have been degrees of sophistication among those who could read and degrees of comprehension among the listening audience. But if there is no fixed line between literate and illiterate, there are roughly zones, the acknowledgment of which in the sagas is crucial not only to the appreciation of their aesthetics, but to an understanding of the peculiar place they occupy in medieval literary history. The usual pattern in oligoliterate societies is for the literate and the illiterate sectors to part ways, each pursuing its own tastes in narrative entertainment. Something like this must have happened in Norway, with the development of a relatively sophisticated court literature on one hand and an unknown quantity of popular tradition on the other-unknown precisely because literate people were not there to cultivate or record it. But in Iceland, which had no court and where the literary forum was distinctly mixed by virtue of social circumstances (as Walter Baetke in particular has emphasized), ${ }^{96}$ there was no such opportunity for a radical split; the literate and the illiterate did not diverge, but necessarily cooperated on a form of narrative that accommodated both of them. That narrative had oral origins, and it retained its oral characteristics sufficiently to entertain a listening audience. But the literary elite was in the meantime reshaping native traditions into forms that are identifiably literary and strikingly similar to those found in other European literature from the same period. Like other unnatural unions, this one between literate and illiterate in Iceland produced a hybrid. Where there was no such union, as in Norway and Denmark, there was no classical saga; and when, as in Iceland itself during the following centuries, there was a waning of the specifically literary vitality (for reasons perhaps having to do with the cultural isolation in the postmedieval period), the balance was disturbed, and saga art reverted to a more popular idiom.

Saga scholarship has made much of the importance of historical traditions, in particular genealogical traditions, in determining the compositional shape of the sagas. In Heusler's words, their "fourfold multiplicity—in plot, space, time, cast of characterspoints toward a derivation in a matter-laden chronicle of

${ }^{96}$ Baetke, Über die Entstehung der Isländersagas, pp. 99-108. 
events."97 The line of continuity between Landnámabók and the individual Icelandic sagas and, further, such compilations as Mođruvallabók and Sturlunga saga, is a very clear one. But to say, as Ker does, that the form of the saga is for this reason largely indebted to circumstances outside of art ${ }^{98}$ ignores the fact that a large proportion of European narrative, including traditions unencumbered by genealogical concerns or indeed historical concerns of any kind, displays a very similar sort of art. The sagas are non-Aristotelian in much the same way that their European neighbors are non-Aristotelian. Open composition, compound structure, internal digression, abundance of particulars, cyclic tendencies, simultaneous narration, and the pursuit of multiplicity for its own sake are medieval characteristics, not just saga peculiarities. The question is not of theme determining matter, but of matter being brought into the thematic sphere. The underlying principle is not that of unity in the classical sense, but rather of the "irritatingly enigmatic" logic of cohesion preferred by medieval authors, particularly in the French tradition. ${ }^{99}$ This is not to deny the role played by local historical traditions in determining the composition of the Icelandic saga, but to suggest that the aesthetic climate of thirteenth-century Europe favored the use of complex and digressive forms (not to speak of prose) in imaginative literature; if the subject matter was inherently digressive to begin with, as Icelandic local traditions in particular must have been, so much the better. The sagas themselves, and the manuscripts in which they are contained, offer prima facie evidence that this literary climate was by no means restricted to Continental authors, but prevailed in Scandinavia as well. That saga composition was influenced by Latin history writing is clear. Whether it also received reinforcing secondary impulses from French prose romance is not clear, though circumstantial evidence points in that direction. In either case, it is with the prose romances, not with epic, that the sagas bear formal comparison. However dis-

\footnotetext{
${ }^{97}$ Andreas Heusler, Die altgermanische Dichtung, 2d ed. rev. (Potsdam: Athenaion, 1941), p. 221. All of Heusler's "proofs" of the chronicle impulse in the Icelandic family sagas stand as descriptions of interlace composition.

${ }^{98}$ W. P. Ker, Epic and Romance, 2d ed. (London: Macmillan, 1906; rpt. New York: Dover, 1957), p. 184.

${ }^{99}$ Albert Pauphilet, Le legs du moyen âge: Etudes de littérature médiévale (Melun: Libraire d'Argences, 1950), p. 214.
} 
tinctive the style and sober vision of the sagas, and however much their temper seems to associate them with heroic traditions, their composition, especially their extended and gratuitous interweaving of plots, associates them with those books of chivalry the Renaissance critics found distastefully digressive and the Canon of Toledo condemned as multilimbed monsters. ${ }^{100}$ From the perspective of medieval aesthetics, it is of some interest that interlace literature has a substantial representation in the north. From the perspective of Scandinavian cultural history, it is correspondingly important to understand that in the central aspect of their composition the sagas are not so anomalous as they are often taken to be, but belong to the common enterprise.

${ }^{100}$ See chapter 1 , note 79 , above. 